\title{
Nutritional and Sensory Quality of Table Olives
}

\author{
Barbara Lanza
}

Additional information is available at the end of the chapter

http://dx.doi.org/10.5772/51723

\section{Introduction}

Table olives are greatly consumed mainly by Mediterranean Sea area populations. The italian cuisine, for example, offers many dishes, aperitifs and appetizer in which olives are an essential ingredient: fish and meat cooked with olives, table olive-based condiments for pasta and pizza, bread-dough mixed with green/black olives, bruschetta with olive paste, and so on. The gastronomic uses of olives are widely and very well-known, but the same cannot be said about its nutritional, nutraceutical and sensory properties. The various Italian olive cultivars with remarkable aptitude for processing as table olives have allowed the development of specific and diversified process technologies. Both chemical and biological treatments perform the dual function of hydrolyzing the compounds responsible for the bitter taste of olive fruit and stabilizing the end product to overcome the constraint of seasonal production. All technological interventions have negative collateral effects that must be minimized or at least kept under control to avoid compromising the quality of the processed product to satisfy the expectation, of the consumer, directed towards natural or minimally processed products, whose nutritional properties and health benefits remain unaltered.

The most important production zones of table olives are located in the Mediterranean area and their consumption is expanding, due to the increasing popularity of the Mediterranean diet (Table 1). In Italy, during the last three years, the average consumption of table olives was approximately 124.000 tonnes/year with a pro-capite assumption of $2.1 \mathrm{~kg} / \mathrm{year}$. The Italian production covers only $48.1 \%$ of the consumers demand, the remaining part is imported from Spain and Greece.

The Italian table olive-growing boasts millenary traditions and its history is an integral part of Italian culture, since its first inhabitants, in prehistoric epoch, used the alimentary resources offered by the primitive Mediterranean "Macchia" and began to domesticate the wild olive tree. Among the over 500 varieties of Olea europaea on the national territory only a 
fraction is specifically suitable for processing as table olives. Italy is rich in typical table olive products, obtained by traditional methods, many of which have obtained or aspired to the recognition of trademarks (PDO, PGI, TAP). The reference to the origin through the Protected Designation of Origin and the Protected Geographical Indication gives to the product added value and it is greatly appreciated by the consumer. The Italian PDO recognized are only three, "Nocellara del Belice" (Sicilia), "La Bella della Daunia" (Puglia) and "Oliva Ascolana del Piceno" (Marche and Abruzzo). The trademark "Traditional Agrifood Products-TAP" (Decree of Italian Ministry of Agriculture 18 July 2000; XII Revision of 7 June 2012) indicate those food products whose methods of processing are consolidated and have been used for a period not less than 25 years. Italy recognize many traditional table olive products, thanks to the country tradition that has passed to the present unique and singular processing technologies for table olives, reflecting the different realities that characterize the different Italian regions (Table 2).

\begin{tabular}{|c|c|c|c|c|c|c|c|c|}
\hline Country/Year & $1990 / 1$ & $1995 / 6$ & $2000 / 1$ & $2005 / 6$ & $2008 / 9$ & 2009/10 & 2010/11* & 2011/12** \\
\hline Spain & 100.0 & 116.0 & 163.6 & 214.1 & 147.7 & 107.9 & 150.0 & 200.0 \\
\hline Greece & 33.0 & 30.0 & 25.0 & 28.0 & 20.0 & 20.0 & 25.0 & 23.0 \\
\hline Portugal & 19.0 & 11.0 & 12.9 & 9.4 & 12.7 & 7.0 & 7.0 & 7.0 \\
\hline Italy & 138.0 & 125.0 & 145.0 & 139.0 & 138.5 & 122.4 & 125.0 & 125.0 \\
\hline France & 31.7 & 28.0 & 39.0 & 53.9 & 53.0 & 56.8 & 58.0 & 59.5 \\
\hline Germany & 15.8 & 21.5 & 35.0 & 40.0 & 47.2 & 57.8 & 67.2 & 72.0 \\
\hline Romania & 5.0 & 10.0 & 9.5 & 10.5 & 16.5 & 22.9 & 23.0 & 23.0 \\
\hline UK & 3.4 & 6.4 & 13.8 & 26.8 & 28.7 & 33.7 & 35.6 & 35.6 \\
\hline Other UE countries & 0.5 & 4.2 & 17.0 & 42.9 & 85.0 & 81.6 & 83.9 & 75.6 \\
\hline Total UE & 346.4 & 352.1 & 460.8 & 564.6 & 549.3 & 510.1 & 574.7 & 620.7 \\
\hline Egypt & 11.0 & 48.0 & 57.0 & 170.0 & 360.0 & 340.0 & 200.0 & 300.0 \\
\hline Turkey & 110.0 & 129.0 & 125.0 & 221.0 & 240.0 & 260.0 & 260.0 & 290.0 \\
\hline Syria & 60.0 & 71.0 & 110.0 & 102.0 & 94.0 & 116.0 & 119.0 & 125.0 \\
\hline Algeria & 14.0 & 14.5 & 33.0 & 80.0 & 97.5 & 134.0 & 129.0 & 137.0 \\
\hline USA & 169.5 & 149.0 & 185.0 & 220.0 & 210.0 & 203.0 & 240.0 & 240.0 \\
\hline Russia & 4.0 & 6.0 & 21.0 & 45.0 & 90.0 & 67.0 & 72.5 & 75.0 \\
\hline Brazil & 41.0 & 46.8 & 45.0 & 55.5 & 69.0 & 79.0 & 87.0 & 87.0 \\
\hline Canada & 12.0 & 13.5 & 20.5 & 25.0 & 26.0 & 27.5 & 27.5 & 28.0 \\
\hline Chile & 6.0 & 8.0 & 9.0 & 11.5 & 21.0 & 29.0 & 30.0 & 32.0 \\
\hline Peru & 14.0 & 15.0 & 9.0 & 19.0 & 25.5 & 50.0 & 50.0 & 50.0 \\
\hline Australia & 7.5 & 9.5 & 14.0 & 18.5 & 19.0 & 20.5 & 22.5 & 22.5 \\
\hline Other countries & 161.6 & 180.4 & 214.2 & 314.9 & 308.7 & 362.9 & 392.8 & 380.3 \\
\hline Total World & 957.0 & 1042.8 & 1303.5 & 1829.0 & 2110.0 & 2199.0 & 2205.0 & 2387.5 \\
\hline
\end{tabular}

Table 1. Table olive consumption. Data are expressed as 1000 tonnes. Source: International Olive Council (November 2011). * provisional; ${ }^{* *}$ previsional. 


\begin{tabular}{|c|c|c|}
\hline Region & Traditional Agrifood Product (TAP) & Cultivar \\
\hline Sicilia & oliva nebba, oliva nera passuluni & Nocellara del Belice \\
\hline Calabria & $\begin{array}{l}\text { olive alla calce, olive in salamoia, olive nella giara, } \\
\text { olive nere infornate, olive schiacciate, olive sotto sale }\end{array}$ & $\begin{array}{l}\text { Carolea } \\
\text { Tonda di Strongoli } \\
\text { Cassanese } \\
\text { Borgese }\end{array}$ \\
\hline Basilicata & olive nere secche, oliva da forno di Ferrandina & Majatica \\
\hline Puglia & $\begin{array}{l}\text { oliva da mensa (mele di bitetto, ualie dolc), olive } \\
\text { cazzate o schiacciate, olive celline di Nardò in concia } \\
\text { tradizionale - olive in concia (ciline alla capàsa - volie } \\
\text { alla capàsa), olive in salamoia, olive verdi, Peranzana } \\
\text { da mensa di Torremaggiore }\end{array}$ & $\begin{array}{l}\text { Termite di Bitetto } \\
\text { Ogliarola leccese } \\
\text { Bella di Cerignola } \\
\text { Cellina di Nardò } \\
\text { Peranzana }\end{array}$ \\
\hline Campania & $\begin{array}{l}\text { olive pisciottane schiacciate sott'olio, oliva caiazzara, } \\
\text { oliva vernacciola di Melizzano }\end{array}$ & $\begin{array}{l}\text { Pisciottana } \\
\text { Caiazzana } \\
\text { Vernacciola }\end{array}$ \\
\hline Lazio & $\begin{array}{l}\text { olive da mensa bianche e nere (olive calce e cenere, } \\
\text { olive di Gaeta, oliva bianca di Itri, olive al fumo, olive } \\
\text { sott'olio, olive spaccate e condite, olive in salamoia, } \\
\text { olive essiccate), pestato di olive di Gaeta }\end{array}$ & $\begin{array}{l}\text { Itrana } \\
\text { Carboncella }\end{array}$ \\
\hline Abruzzo & olive Intosso (olive n'dosse, olive in salamoia) & Intosso \\
\hline Molise & olive al naturale (live curvate, olie all'acqua e sale) & $\begin{array}{l}\text { Sperone di gallo } \\
\text { Olivone } \\
\text { Olivoncello } \\
\text { Leccino } \\
\end{array}$ \\
\hline Marche & olive nere marinate (olive nere strinate), salsa di olive & $\begin{array}{l}\text { Raggiola } \\
\text { Raggia } \\
\text { Piantone di Falerone } \\
\text { Leccino } \\
\end{array}$ \\
\hline Toscana & olive in salamoia & $\begin{array}{l}\text { Leccino } \\
\text { Frantoio }\end{array}$ \\
\hline Liguria & olivo taggiasca & Taggiasca \\
\hline Sardegna & olive a scabecciu, olive verdi in salamoia & $\begin{array}{l}\text { Tonda di Cagliari } \\
\text { Pizz'e Carroga }\end{array}$ \\
\hline
\end{tabular}

Table 2. TAP table olives (XII Revision - 2012).

\section{Preparations and styles}

The numerous Italian olive cultivars with remarkable aptitude for processing as table olives have allowed the development of specific and diversified process technologies. The Italian table olive production is mainly concentrated in the Southern and Central regions of Italy (Figure 1). 


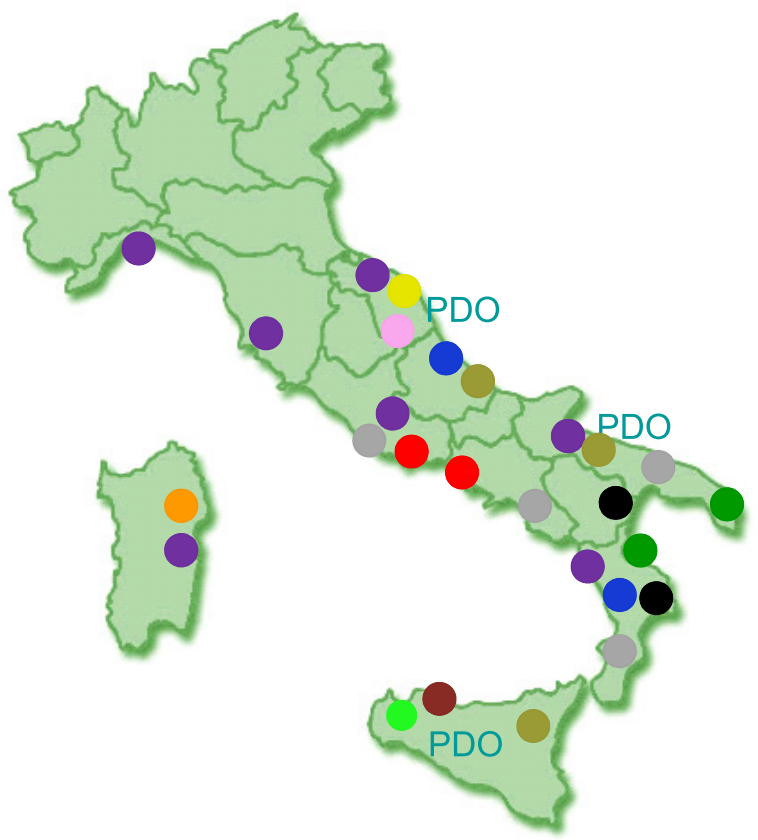

\begin{tabular}{|c|}
\hline $\begin{array}{l}\text { Sweet green olives by } \\
\text { Castelvetrano -style }\end{array}$ \\
\hline $\begin{array}{l}\text { Oven-dried black olives } \\
\text { by Ferrandina -style }\end{array}$ \\
\hline $\begin{array}{l}\text { Treated green olives in } \\
\text { brine by Sevillan -style }\end{array}$ \\
\hline $\begin{array}{l}\text { Green olives by lime - } \\
\text { and-ash treatment }\end{array}$ \\
\hline Crushed olives \\
\hline $\begin{array}{l}\text { Natural green and black } \\
\text { olives by Itrana -style }\end{array}$ \\
\hline $\begin{array}{l}\text { Natural olives by Greek- } \\
\text { style }\end{array}$ \\
\hline Dry-salted black olives \\
\hline "Scabecciu " olives \\
\hline $\begin{array}{l}\text { Stuffed olives by } \\
\text { Ascolana -style }\end{array}$ \\
\hline "Strinate" olives \\
\hline "Passuluna "olives \\
\hline
\end{tabular}

Figure 1. Regional distribution of Italian table olive production.

The main Italian table olive preparations are the following:

\subsection{Treated olives}

The "treated olives", according to "Trade Standard Applying to Table Olives" (IOC, 2004) are "green olives, olives turning color or black olives that have undergone alkaline treatment, then packed in brine in which they undergo complete or partial fermentation, and preserved or not by the addition of acidifying agents".

\subsubsection{Treated green olives in brine by Sevillan-style}

This method is also known as Sevillan or Spanish-style and it is one of the most common and oldest methods for Italian green table olives (Tavanti, 1819). To obtain the "treated green olives in brine", the fruits are debittered with $\mathrm{NaOH}$ aqueous solution ranging from $2.0 \%$ to $3.5 \%$, mainly depending on the variety and ripeness of the olives. The alkaline treatment performs the function of hydrolyzing the compound principally responsible for the bitter taste (oleuropein). The lye solution completely covers the fruits and the olives remain in this solution until the lye has penetrated between $2 / 3$ and $3 / 4$ of the distance 
between the skin and the pit. To verify a correct lye treatment, olives are cut with a particularly sharp blade such as razor blade or scalpel near the pit, checking the surface after air exposition. After alkaline treatment, the olives are washed with potable water. The sequence of washings is the following:

- the first one is a strong washing with potable water made using a shower lasting 15-20 minutes in order to eliminate the lye attached to the fruit surface; the olives washed are then left in the final washing water

- after 2-3 hours a second faster and simpler washing takes place using a fillingemptying procedure

- $\quad$ in the following 24-48 hours 3-4 other washings are carried out, using always a fillingemptying procedure.

After water-washings to eliminate the residual lye, olives are covered with a sodium chloride solution (brine) and left to develop a spontaneous lactic fermentation. Initial brine concentrations are $8-10 \% \mathrm{NaCl}$ but rapidly drop to $5 \%$ due to the high content of interchangeable water in the olives. A spontaneous fermentation starts as soon as the olives are placed in brine. After alkaline treatment, the $\mathrm{pH}$ of olive flesh reaches the value of 11.013.0 down to the value of 8.0-9.0 after the repeated washings. In this broth culture, a complex and variable microbiota grows. Reducing sugars and glucosides, the basic sources of carbon needed in the development of lactobacilli and other microrganisms, pass from olive flesh to the brine, where they are used by heterofermentative or homofermentative microrganisms to produce lactic acid. In the first phase of fermentation, when Gramnegative bacteria prevail, the $\mathrm{pH}$ ranges from 8.0-9.0 to about 6.0. This low $\mathrm{pH}$ promotes the growth of lactic acid bacteria that are aciduric with optimal growth between $\mathrm{pH} 5.5$ and 5.8 . At the end of lactic fermentation, the $\mathrm{pH}$ reaches values $<4.0$ and acidity increases, ensuring thus the preservation of the product. The lactic fermentation ends with the exhaustion of available carbohydrates (glucose from glucosides and reducing sugars). Several researches have been carried out to evaluate the technological functionality of selected lactic acid bacteria or enterococci in Spanish-style green olive processing. Enterococcus casseliflavus and Lactobacillus pentosus (de Castro et al., 2002; Sánchez et al., 2001) have been proposed as starter cultures to accelerate lactic acid formation at $\mathrm{pH} 9$ (immediately after washings). In this case, obviously, the strain used as starter is not necessarily oleuropeinolytic because lye has just demolished the bitter glucoside. The importance of this type of starter is to reduce the lag phase and the risk of spoilage (Bevilacqua et al., 2010; Ruiz-Barba et al., 1994; LealSanchez et al., 2003). As a result of ill-treatment alkali set or poorly conducted, the tissues of the fruit may also undergo profound changes in structural and nutritional constituents (Marsilio \& Lanza, 1995).

\subsubsection{Sweet green olives by Castelvetrano-style}

This is a production method used in Sicilia, almost exclusively in the Castelvetrano district using the Nocellara del Belice cultivar. The product is mainly consumed in central and southern Italy (Cappello \& Poiana, 2005; Lanza \& Poiana, 2011). The olives are hand- 
harvested at the green stage of ripening and, once they arrive at the processing plant, they are graded, since only fruits of more than $19 \mathrm{~mm}$ in diameter are used. The selected olives are put into plastic vessels and covered with 2.5-3.5 ${ }^{\circ} \mathrm{Bè} \mathrm{NaOH}$ solution (1.7-2.4\%), depending on the fruit ripeness and size. These vessels have $220 \mathrm{~L}$ total capacity, and are filled with around $140 \mathrm{~kg}$ of fruits. Eight hours after the lye treatment begins, 6-7 kg of grinded salt is added to each container, and the olives are kept in this "alkaline brine" for 810 days. Salting is performed by placing the grinded salt over the "press-fruit" of each barrel (Figure 2).

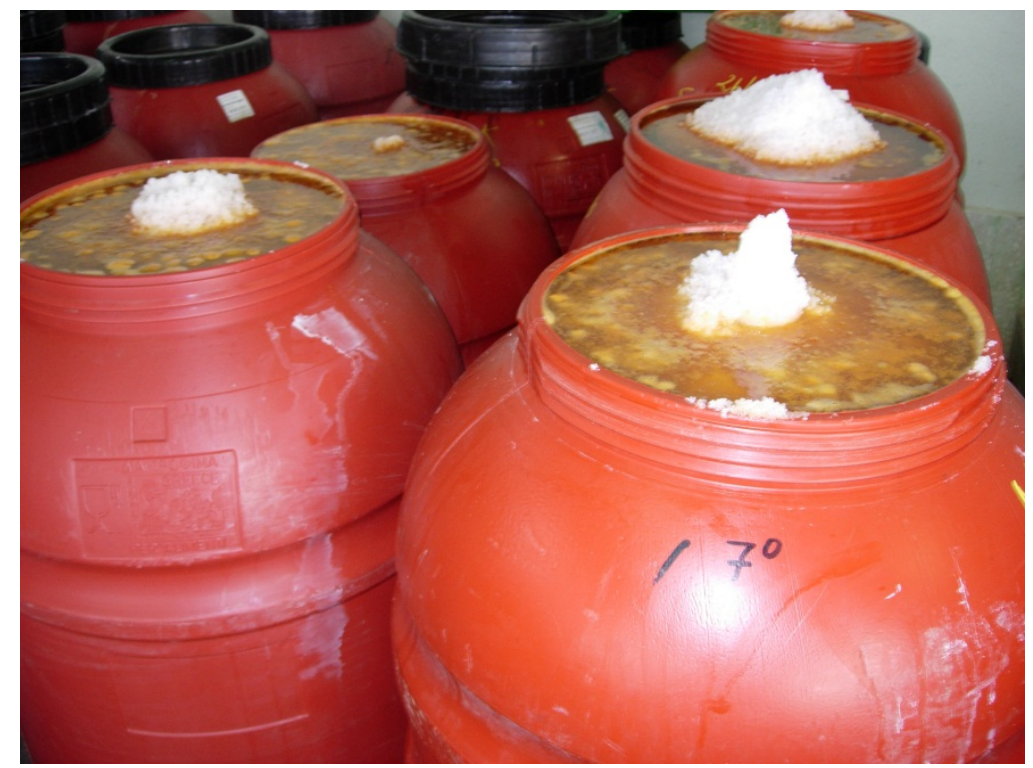

Figure 2. Addition of grinded salt directly on the "press-fruit" at the surface of the barrel (photograph by A. Cappello from Lanza \& Poiana, 2011).

The sodium chloride in contact with the liquid is slowly dissolved and is distributed by gravity in the whole volume of the container. The salt traditionally used in this type of procedure is sea salt coming from the saltworks of Trapani. It is particularly rich in trace elements such as $\mathrm{K}, \mathrm{Mg}, \mathrm{Ca}$, Fe and I, unlike the rock salt composed almost exclusively of $\mathrm{NaCl}$. In this environment, the olives are softened quickly highlighting a deep green color. When the barrel is opened, the lye/salt brine is drained and the olives are washed to remove excess lye. A mild washing step, carried out before marketing, does not totally eliminate the lye, whose "soapy" taste is appreciated by the consumers of these olives. Under ambient storage conditions the Castelvetrano olives have a shelf-life of only a few months, especially under hot conditions. Deteriorated olives lose colour and develop off-odours. As this olive style is a seasonal product, long-term storage is not required. Future research, however, may refine the process and include steps for long-term storage under refrigeration, with the temperature maintained between $4^{\circ} \mathrm{C}$ and $7^{\circ} \mathrm{C}$, or in packing solutions. 


\subsubsection{Green olives by lime-and-ash treatment}

In some Italian regions (Puglia, Campania, Lazio and Calabria), olives are prepared with an ancient and traditional method that includes a debittering phase obtained using a lime-ash mixture, preparing these treated green olives by mixing $\mathrm{CaO}$ (lime) with olive wood ash and adding water to a paste, leaving submerged the green olives for some hours at room temperature. The ratio of lime and ash is different (1:4, 1:8, 1:10, etc) and depends on the cultivar and shape of the fruit. The action of lime-ash is similar to that of $\mathrm{NaOH}$. After alkaline treatment, the olives are washed with potable water. The sequence of washings is similar to the sequence previously described for the treated green olives by Sevillan-style. It is possible to eat these olives right after the debittering treatment or after brining. In this case, after the washing step, olives were placed in an initial brine solution of $\mathrm{NaCl}(8 \% \mathrm{w} / \mathrm{v})$, where a spontaneous fermentation takes place. $\mathrm{NaCl}$ concentration is carefully monitored during this phase. The brine concentration decreases quickly as a consequence of the osmotic phenomena between the brine and the fruits from $8 \%$ to about $5 \%$ in $48-72$ h. For this reason after 4-5 days from brining, grinded salt is added to the brine to restore the initial concentration. After 1-2 months of fermentation olives are ready to eat.

\subsection{Natural olives}

The "natural olives", according to the "Trade Standard Applying to Table Olives" (IOC, 2004) are "green olives, olives turning color or black olives placed directly in brine in which they undergo complete or partial fermentation, preserved or not by the addition of acidifying agents". The most important industrial preparation for natural black olives takes the name "Greek-style" because it is traditionally practiced in Greece utilizing Conservolea cv. (Balatsouras, 1990).

\subsubsection{Natural turning colour olives}

Italy has a long tradition in producing "natural turning colour olives". In this process the olives are directly brined in $8-10 \%$ of sodium chloride. The brine stimulates the microbial activity for fermentation and reduces the bitterness of the oleuropein. Fermentation of these olives takes a long time because diffusion of soluble components through the epidermis, in fruits not treated with alkali, is slow. A diverse microbiota grows in these brines, although yeasts are the microorganisms always present throughout the process. Enterobacteriaceae can be found during the first 7-15 days, but they disappear as the brine characteristics do not support their growth. The presence of lactic acid bacteria depends on the salt concentration and the polyphenol content of the variety used. The traditional brining is carried out under anaerobic conditions. However, an aerobic method can be applied, using a central column in the fermenter through which air is bubbled. This system changes the ratio between fermentative and oxidative yeasts, and a final product with better quality is attained (Garcia Garcia et al., 1985 ; Garrido Fernández et al., 1997). The colour fades during the process, but it is corrected by aerating the olives for two or three days; sometimes they are treated with $0.1 \%$ ferrous gluconate or lactate to make them deep black. Lastly, the olives are selected and 
packed in barrels or in varnished cans, which are filled with $8 \%$ fresh brine. They are popular because of their slightly bitter taste and aroma. When the bitterness has been sufficiently weakened the fruit can be marketed. To reduce the debittering phase, several researches have evaluated the use of selected oleuropeinolytic lactic acid bacteria (LAB) as starter cultures in Greek-style olive processing. Lactobacillus plantarum (Ciafardini et al., 1994; Marsilio et al., 1996; Marsilio \& Lanza, 1998; Marsilio et al., 2005; Panagou et al., 2008) and Lactobacillus pentosus (Panagou et al., 2003; Panagou et al., 2008; Servili et al., 2006), in addition to developing a fast growth and a good acidifying capacity even in the presence of high concentrations of salt (brine), were able to grow in the presence of phenolic compounds (known for their antimicrobial action) and, thanks to the marked oleuropeinolytic activity, degraded the oleuropein in no-bitter compounds, reducing thus considerably the time of debittering.

\subsubsection{Natural green and black olives by Itrana-style}

The Itrana variety is grown mainly in Lazio region and affects the hilly area of Ausoni, Lepini and Aurunci mountains. The production is concentrated in Latina district (Itri, Cori, Rocca Massima and Sonnino). The olives destined to produce the famous "Oliva nera di Gaeta" are harvested at the stage of full maturity in the months of February-March (very late compared to most table olive cultivars). This method provides an initial step of immersion in water for about 1 month to stimulate the growth of specific microflora that contributes to the debittering of the fruits (Lanza, 2010). After 10-30 days salt is added to the liquid, in quantities not exceeding $7 \mathrm{~kg}$ per $100 \mathrm{~kg}$ of fresh olives. After 4-6 months of storage in brine the olive flesh shows a typical red-wine colour and acidic taste probably due to the contribution of heterofermentative bacteria and yeasts. In recent years another type of product named "Oliva bianca di Itri" has evolved. The processing system is basically the same but the Itrana fruits are collected at the beginning of ripening in the months of November-December, when they reach their final size and look green or turning-color, and immersed immediately in water. After 6-8 months, the product results more bitter and acid respect to Gaeta olives and kinesthetic characteristics (hardness, fibrousness and crunchiness) are more pronounced.

\subsubsection{Cracked/crushed olives}

This type of processing is typical of the Calabria, Puglia and Campania regions. In Puglia (Salento) the olives of Ogliarola salentina cv., harvested at the green stage of ripening, are crushed with a wooden hammer (or a crushing machine) taking care not to break the stone, then they are put in an earthenware pot with water for at least 2 weeks changing the water at least twice a day. The olives suitable for this preparation must have a crunchy flesh with a strong detachment of the flesh from the stone. The finished product is seasoned with garlic, pepper, oregano and other spices (local name: volia cazzata). In Calabria (Crotonese) olives of Carolea cv. are similarly prepared (local name: aliva maccata). In Campania (Cilento) the olives of Pisciottana cv. are still prepared according to an ancient recipe that has very special ingredients and an elaborate preparation process. The green olives are picked, washed with a lot of water and left in a bowl, in which powdered lime and ashes are added; everything is 
then covered with water. The bowl is left to rest for 48 hours, then everything is drained and rinsed; the next step is to let the olives steep for 24 hours in a container with salt and bay leaves. After that the olives are drained and laid out on wood or stone board and squashed with a wood pin, until the seeds come away. Once squashed, the olives are gathered and placed in a glass container, they are pressed with the hands and dressed with chili pepper and other spices and condiments and covered with extra virgin olive oil. During the fermentation of cracked green olives, the predominant microorganisms are yeasts while lactic acid bacteria are not detected. The main role of yeasts in the processing of fermented olives, is associated with the production of alcohols, ethyl acetate, acetaldehyde and organic acids, compounds that are relevant for the development of taste and aroma and the preservation characteristics of this fermented food (Alves et al., 2012; Arroyo-Lopez et al., 2008).

\subsection{4. "Scabecciu" olives}

The Scabecciu olives are a traditional preparation typical of Sardegna region. The ripe olives of Tonda di Cagliari and Pizz'e Carroga varieties are engraved in three points, put in brine for about 3 days, washed with water and blanched in vinegar-water and then dried in the sun. Finally, they are fried with garlic and parsley and placed in oil. After about 1 month of preparation they can be consumed as appetizer.

\subsection{Oven-dried black olives by Ferrandina-style}

In Basilicata region, olives are prepared with an ancient and traditional method, Ferrandina method, which name derives from the small city Ferrandina, near Matera, where olive trees of Olea europaea L. Majatica cv. are cultivated (Savastano, 1937; Di Gioia, 1959; Cucurachi et al., 1971). The olives are hand-harvested at the black stage of ripening at the end of November-early December. Initially the olives are blanched in water at $90^{\circ} \mathrm{C}$ for $3 \mathrm{~min}$ to make the skin more permeable and facilitate the osmotic processes. After blanching, the olives are salted with grinded $\mathrm{NaCl}(10: 1 \mathrm{w} / \mathrm{w})$ for 3 days and finally they are placed in single layer and oven-dried in an air-oven at $50{ }^{\circ} \mathrm{C}$ for 36 hours until the humidity is around $8 \%$ and $A_{w}$ around 0.7 . This product is ready to eat in 1 week. The first two steps of the process (blanching and salting) contribute to fruit debittering; the second and the final steps (salting and oven-drying) result in water loss for better preservation of the product. This trade preparation is in accordance with the "Trade Standard Applying to Table Olives" (IOC, 2004) as "dehydrated and/or shrivelled black olives", black olives that have undergone or not mild alkaline treatment, preserved in brine or partially dehydrated in dry salt and/or by heating or by any other technological process. Today, olives from cv. Majatica are almost entirely destined to the production of oil. The production of oven-dried black olives by Ferrandina-style is in drastic decline and manufacturers are few. The product is prevalently exported in the USA and not all olives sold in the Italian market as oven-dried olives originate from cv. Majatica.

Textural changes occurring in oven-dried olive -tissues during each processing step were visualized by scanning electron microscope, texture analyzer, analysis of cell wall 
polysaccharides, pectins and biophenols (Borzillo et al., 2000; Marsilio et al., 2000; Cardoso et al., 2009; Piga et al., 2005). Recently, some authors (Lanza et al., 2012) evaluated chemical and nutrient characteristics of Ferrandina oven-dried table olives with the aim to enhance the value of this end product from a nutritional point of view.

\subsection{Dry-salted black olives}

Salt-dried olives are prepared by packing naturally black-ripe olives in alternating layers with dry coarse salt (equivalent to $10-20 \% \mathrm{w} / \mathrm{w}$ of the weight of olives) and spices (oregano, orange peel, bay leaves, fennel, garlic, etc) in slatted containers that allow drainage of the vegetable water drawn out by the salt. The resulting olives, or 'date olives', are shrivelled in appearance and have a salty bitter-sweet taste (Panagou, 2006). Salt is also taken up by the olive, which acts as a preservative. Processing time is around four to six weeks and the olives are best eaten within three months of processing. Addition of olive oil enhances the flavour of the olive; however, oxidation of the oil can give the olives a rancid taste. In all Italian regions the most common cultivar that is prepared by salt-drying is Leccino cv. but there are also some local variations:

\subsection{1. "Strinate" olives}

In Marche region (areas near Ascoli Piceno and Macerata) black olives from Leccino, Raggiola, Raggia, Piantone di Falerone and Lea cvs. are stored in a jute bag after being combined with coarse salt. The bag, tied with a string, is hang outdoors sheltered from the rain and in a very cold place, taking care to mix the olives twice daily to prevent formation of mold and to promote a better distribution of salt. Under the bag a basin is placed to collect the vegetation water produced by the olives. The low winter temperatures favor the loss of bitter taste and cause dehydration of the olives, which assume a shriveled appearance. After 20-40 days, they are placed in glass containers for storage and with the addition of all the ingredients already described above for the preparation of dry-salted olives. The product thus obtained is called strinate olives from dialectal word that means "dead of cold".

\subsection{2 "Passuluna" olives}

In Sicilia region (Palermo), the passuluna olives are natural over-ripe olives, left on the tree, harvested in December-January, washed with hot water and leave to air-dry. Really, those olives are shriveled and debittered as the result of attack of the fungus Camarosporium dalmaticum, introduced in the drupe from dipteran Prolasioptera berlesiana, parasite of Bactrocera oleae eggs.

\subsection{Stuffed olives by Ascolana-style}

The stuffed olives by Ascolana-style are prepared from treated green olives in brine from Ascolana tenera cv. (PDO “Oliva Ascolana del Piceno). The meat (beef 40-70\%; pork 30-50\%; 
chicken/turkey max $10 \%$ ) is triturated and browned with onion, carrot and celery in olive oil and cooked on low heat with the addition of dry white wine and salt. When cooked, meat and add-ingredients are shredded and combined with beaten egg, grated cheese and ground nutmeg. The pre-pitted olives are filled with the mixture, are dipped in flour, then beaten egg and finally in breadcrumbs. The final product is intended for frying.

\section{Nutritional and nutraceutical characterization}

Table olives are a complete food from a nutritional point of view (Cannata, 1939). It is a drupe consisting primarily of water, fat, carbohydrates, protein, fiber, pectin, biophenols, vitamins, organic acids and mineral elements. The quality of this product is linked to the combined effect of various factors, such as the suitability of raw materials, the processing technologies, the nutritional composition and, in no small measure, the sensory properties.

Olive fruit is a drupe, constituted by three distinct anatomical zones: epicarp (skin), mesocarp (pulp) and endocarp (stone) containing the seed. All three influence the quality of the end product (Garrido Fernández et al., 1997; Montaño et al., 2010). The epicarp and mesocarp constitute the edible part of the olive fruit that is around 70-85\%. Information on the nutritional composition is related to $100 \mathrm{~g}$ of edible portion (e.p.) (Table 2).

The energy value of $100 \mathrm{~g}$ of e.p. of Italian olives is around 200-250 kilocalories with some exceptions (455 kcal for Majatica olives and $164 \mathrm{kcal}$ for Bella di Cerignola olives; Table 3). This value, referred to a diet of $2000 \mathrm{kcal}$ for an adult of average build with limited physical activity, accounts for $10-12.5 \%$ of total calories.

\begin{tabular}{|c|c|c|c|c|c|c|c|c|c|}
\hline $\begin{array}{l}\text { Nutrients/ } \\
100 \text { g e.p. }\end{array}$ & $\begin{array}{l}\text { Sevillan } \\
\text { green } \\
\text { olives } \\
\text { Intosso }\end{array}$ & $\begin{array}{c}\text { Sevillan } \\
\text { green } \\
\text { olives } \\
\text { Bella di Cerignola }\end{array}$ & $\begin{array}{c}\text { Castelvetrano } \\
\text { green } \\
\text { olives } \\
\text { Nocellara B. }\end{array}$ & $\begin{array}{c}\text { Ferrandina } \\
\text { black } \\
\text { olives } \\
\text { Majatica }\end{array}$ & $\begin{array}{c}\text { Natural } \\
\text { black } \\
\text { olives } \\
\text { Taggiasca }\end{array}$ & $\begin{array}{c}\text { Natural } \\
\text { black } \\
\text { olives } \\
\text { Peranzana }\end{array}$ & $\begin{array}{c}\text { Natural } \\
\text { black } \\
\text { olives } \\
\text { Itrana }\end{array}$ & $\begin{array}{c}\text { Natural } \\
\text { green } \\
\text { olives } \\
\text { Itrana }\end{array}$ & $\begin{array}{c}\text { Natural } \\
\text { black } \\
\text { olives } \\
\text { Cellina } N \text {. }\end{array}$ \\
\hline Energy kcal & 190 & 164 & 204 & 455 & 226 & 247 & 235 & 193 & 223 \\
\hline Proteins $g$ & 1.0 & 1.2 & 1.0 & 2.2 & 1.5 & 1.7 & 1.4 & 1.5 & 1.3 \\
\hline $\begin{array}{l}\text { Carbohydrates } g \\
\text { Sugars } g\end{array}$ & $\begin{array}{c}2.8 \\
\operatorname{tr}\end{array}$ & $\begin{array}{c}2.5 \\
<0.6\end{array}$ & $\begin{array}{l}3.6 \\
0.4\end{array}$ & $\begin{array}{c}\text { n.d. } \\
4.4\end{array}$ & $\begin{array}{c}8.9 \\
\operatorname{tr}\end{array}$ & $\begin{array}{l}5.8 \\
0.6\end{array}$ & $\begin{array}{l}6.5 \\
0.3\end{array}$ & $\begin{array}{l}5.0 \\
0.6\end{array}$ & $\begin{array}{l}7.2 \\
1.7\end{array}$ \\
\hline Fats $g$ & 17.5 & 15.5 & 19.8 & 46.9 & 19.9 & 23.2 & 21.7 & 17.7 & 19.9 \\
\hline SFA $g$ & 2.7 & 2.1 & 3.9 & 6.3 & 3.7 & 4.1 & 2.7 & 2.8 & 4.4 \\
\hline MUFA $g$ & 13.6 & 12.5 & 13.9 & 36.7 & 15.2 & 17.0 & 17.7 & 14.0 & 14.5 \\
\hline PUFA $g$ & 1.2 & 0.9 & 2.0 & 4.0 & 0.9 & 2.1 & 1.3 & 0.9 & 1.0 \\
\hline Fiber $g$ & 2.6 & 4.8 & 3.8 & 3.4 & 2.6 & 4.1 & 4.0 & 3.6 & 4.8 \\
\hline Sodium $g$ & 1.3 & 1.1 & 0.9 & 0.9 & 1.8 & 1.4 & 1.5 & 1.2 & 1.5 \\
\hline Calcium $m g$ & 33.6 & 34.9 & n.d. & 168.1 & 92.7 & 83.1 & 28.9 & 21.9 & 58.7 \\
\hline Polyphenols $m g$ & 168 & 104 & 24 & 263 & 206 & 334 & 211 & 109 & 299 \\
\hline
\end{tabular}

Table 3. Nutritional characteristics of some Italian table olives. n.d. $=$ not detected; $\operatorname{tr}=\operatorname{traces}$.

The protein content is low (1.0-2.2 g; Table 3), but nutritional quality is high for the presence of essential amino acids for adults, threonine, valine, leucine, isoleucine, phenylalanine and lysine (Young, 1994), and for childrens, arginine, histidine and tyrosine (Imura \& Okada, 
1998). Aspartic and glutamic acids are the most representative amino acids, however in some preparations threonine, valine, leucine and arginine contents are $>100 \mathrm{mg}$ (Table 4 ). These results are confirmed by other authors for other cultivars and treatments (Lanza et al., 2010; Lazovic et al., 1999; López et al., 2007; López-López et al., 2010b; Montaño et al., 2005).

\begin{tabular}{|c|c|c|c|}
\hline $\begin{array}{l}\text { Amino acid } \\
\text { (mg/100g e.p.) }\end{array}$ & $\begin{array}{c}\text { Treated green } \\
\text { olives } \\
\text { Intosso }\end{array}$ & $\begin{array}{c}\text { Ferrandina } \\
\text { black } \\
\text { olives } \\
\text { Majatica } \\
\end{array}$ & $\begin{array}{c}\text { Natural black } \\
\text { olives } \\
\text { Peranzana }\end{array}$ \\
\hline Aspartic acid & 150 & 214 & 131 \\
\hline Threonine & 70 & 129 & 80 \\
\hline Serine & 80 & 124 & 74 \\
\hline Glutamic acid & 150 & 226 & 128 \\
\hline Proline & 50 & $\operatorname{tr}$ & $\operatorname{tr}$ \\
\hline Glycine & 70 & 115 & 65 \\
\hline Alanine & 80 & 115 & 66 \\
\hline Valine & 60 & 104 & 63 \\
\hline Isoleucine & 100 & 86 & 50 \\
\hline Leucine & 140 & 173 & 98 \\
\hline Phenylalanine + Tyrosine & 100 & 168 & 117 \\
\hline Lysine & 10 & 18 & $\operatorname{tr}$ \\
\hline Histidine & 30 & 26 & 28 \\
\hline Arginine & 70 & 120 & 68 \\
\hline Other amino acids & $\operatorname{tr}$ & $\operatorname{tr}$ & $\operatorname{tr}$ \\
\hline
\end{tabular}

Table 4. Amino acid pattern of some Italian table olives. $\operatorname{tr}=$ traces.

The carbohydrate content in the olive fruit is, by itself, lower than any other edible fruit (Marsilio et al., 2001). However, table olives have even lower proportions of these compounds since during the fermentation process or brine storage the microorganisms present in brines consume sugars. Then table olives can be considered as practically free of sugar products. Therefore, the calculation of total carbohydrates as difference, as must be made for nutritional labeling in the US, may lead to an overestimation of the amounts of these compounds in table olives, resulting in an error for consumers. However, unfermented products such as Ferrandina olives, appreciable quantities $(4.4 \mathrm{~g})$ of simple sugars are present (Table 3).

Table olives are a good source of dietary fibre, which in addition, has a high digestibility rate (Jimenez et al., 2000; López-López et al., 2007). In European Union countries (Reg. CE $1924 / 2006$ and Reg. UE 116/2010) it is possible to write on the label the claim "source of fibre" if the product contains at least $3 \mathrm{~g}$ of fiber $/ 100 \mathrm{~g}$ of e.p. If the product contains at least 
$6 \mathrm{~g}$ of fiber/ $100 \mathrm{~g}$ of e.p. (as it can be the case for some varieties) the claim "with high content of fiber" could be used. Most preparations have a content of fibre $\geq 3 \mathrm{~g} / 100 \mathrm{~g}$ of e.p., so they can be considered as a source of fibre (Table 3).

It is worth highlighting on table olives mineral content. Discrete calcium content was found in some samples (168.1 mg for Majatica, $92.7 \mathrm{mg}$ for Taggiasca and $83.1 \mathrm{mg}$ for Peranzana; Table 3). The contribution of this element, albeit insignificant, contributes along with other foods to reach the daily requirement of calcium which is $800 \mathrm{mg}$. The high Na content of some traditional preparations ( $\geq 1.5 \mathrm{~g}$; Table 3$)$, resulting by fermenting and packing brines, is not in contrast with sodium RDV by Dietary Guidelines for Italians (LARN, 1996), that consists of $2.27 \mathrm{~g} /$ day. The consumption of these table olives may be unadvisable only in hypertensive pathologies. There are some studies (Bautista Gallego et al., 2011; Marsilio et al., 2000; Panagou et al., 2011) on use of alternative chloride salt mixtures in substitution of common salt $(\mathrm{NaCl})$ to reduce the intake of sodium, with an exception of the dry-salted olives $(4-10 \mathrm{~g} / 100 \mathrm{~g}$ of e.p.) (Figure 3$)$.

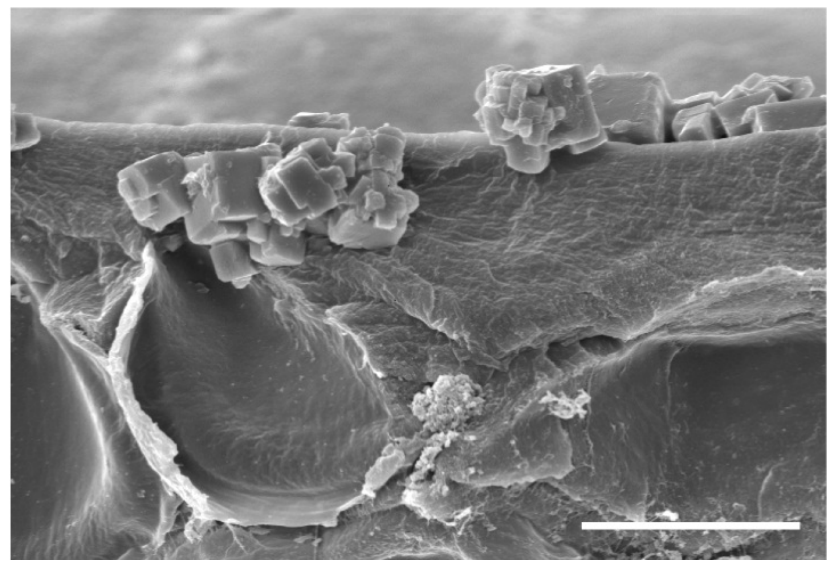

Figure 3. $\mathrm{NaCl}$ crystals on olive skin. Bar $=15 \mu \mathrm{m}$.

Table olives are also rich in natural antioxidants such as vitamins. They provide small amounts of B group vitamins as well as liposoluble vitamins such as pro-vitamin A and vitamin E, considered to have great antioxidant effects. The vitamin $\mathrm{C}$ content is low $(<1$ $\mathrm{mg} / \mathrm{kg}$ of e.p.). Many green olive commercial presentations add, as antioxidant, ascorbic acid, which becomes a part of their final ingredients and increases the vitamin $C$ content of the product. This compound may be progressively lost during shelf life, but depending on the time elapsed from packing, such table olives may eventually represent an interesting source of vitamin C.

All table olives analyzed (except Nocellara del Belice olives) are, despite treatments, still rich in natural antioxidants such as polyphenols (Table 3) and their antioxidant capacity and functional effects on human wellbeing is well ascertained (Baiano et al., 2009; Ben Othman et al., 2008; Boskou et al., 2006). Table olives contain simple and complex phenolic compounds 
(at least 30 different phenolic compounds) in amounts ranging between 100 and 350 $\mathrm{mg} / 100 \mathrm{~g}$ of e.p. (the same quantity of $1 \mathrm{~kg}$ of extra virgin olive oil!). It was demonstrated that the variability of those main phenolic compounds can be related to a combination of agronomic and/or technological processes. The polyphenol content and composition depends on several factors such as cultivar, stage of ripening, location and processing (Blekas et al., 2002; Bianchi, 2003; Romero et al., 2004). Recent research has focused on a phenolic compound of nutraceutical value, oleocanthal (dialdehydic form of deacetoxyligstroside aglycon) as NSAI-like drugs (non-steroidal anti-inflammatory drugs), with Ibuprofene-like activity (Beauchamp et al., 2005).

Organic acids (oxalic, succinic, malic, citric and lactic) are present in rather low percentage, such as to give the olive pulp a total acidity between $4-10 \mathrm{~g} / \mathrm{kg}$ (expressed as citric acid) and a $\mathrm{pH}$ between 3.8 and 5.0. The content of oxalic and malic acids decreases in the course of maturation and the content of citric acid increases, while succinic acid seems to remain constant. In addition, the ratio of citric and malic acids decreases in the course of maturation to reach, at the moment of maximum oil accumulation (inolition), values close to 1 (Garrido Fernández et al., 1997).

Crude fat content was determined by extraction in a Soxhlet apparatus, according to the procedures described previously for olives (Lanza et al., 2010a). The olive product with the lowest fat content was that of Bella di Cerignola processed with the Sevillan method (15.5 g), while the highest was that of Majatica oven-drying by Ferrandina-style (46.9 g). It is noticeable the difference between the fat content of Itrana processed as "Oliva Bianca di Itri" and "Oliva Nera di Gaeta" (17.7 and 21.7 g, respectively) is certainly due to the different periods of harvesting and maturation.

To analyze the fat composition, the olive fruits were pitted and triturated with a grinder. The olive paste was warmed up in a water bath at $28 \pm 2{ }^{\circ} \mathrm{C}$ for $30 \mathrm{~min}$ and the oil was extracted by centrifugation at $5000 \mathrm{rpm}$ for $30 \mathrm{~min}$. The resulting surnatant oil, preleased with a Pasteur pipette, was filtered in the presence of Na-sulphate anhydrous and stored at $4{ }^{\circ} \mathrm{C}$ in aluminum foil wrapped falcon tubes until analyses. This procedure simulates the extraction of olive oil in olive mill (crushing, mixing and centrifugation) and was used to prevent changes in the oil quality as much as possible (Lanza et al., 2012).

Table 5 shows the detailed fatty acid composition (relative percentage within the lipid fraction) of oil extracted from for different table olives. Oleic acid is the predominant one (63.4-80.7\%), palmitic acid was the second most abundant fatty acid (9.8-19.6\%), followed by linoleic acid (4.7-13.6 \%) and stearic acid (1.6-3.0 \%), a pattern common to most reported data (Lanza et al., 2010a; Sousa et al., 2011; Sakouhi et al., 2008; Borzillo et al., 2000; López et al., 2006; López-López et al., 2010a; Ünal \& Nergiz, 2003; Issaoui et al., 2011). Recent research showed that intestinal mucosal cells utilize dietary oleic acid as a substrate to produce the lipid messenger oleoylethanolamide (OEA) that plays an important role in the regulation of animal food intake and body weight in human physiological and pathophysiological conditions (Schwartz et al., 2008). 


\begin{tabular}{|c|c|c|c|c|c|c|c|c|}
\hline Fatty acids & $\begin{array}{c}\text { Sevillan } \\
\text { green } \\
\text { olives } \\
\text { Intosso }\end{array}$ & $\begin{array}{l}\text { Sevillan } \\
\text { green } \\
\text { olives } \\
\text { Bella di } \\
\text { Cerignola }\end{array}$ & $\begin{array}{c}\text { Ferrandina } \\
\text { black } \\
\text { olives } \\
\text { Majatica }\end{array}$ & $\begin{array}{c}\text { Natural } \\
\text { black } \\
\text { olives } \\
\text { Moresca }\end{array}$ & $\begin{array}{c}\text { Natural } \\
\text { black } \\
\text { olives } \\
\text { Peranzana }\end{array}$ & $\begin{array}{c}\text { Natural } \\
\text { black } \\
\text { olives } \\
\text { Itrana }\end{array}$ & $\begin{array}{l}\text { Natural } \\
\text { green } \\
\text { olives } \\
\text { Itrana }\end{array}$ & $\begin{array}{c}\text { Natural } \\
\text { black } \\
\text { olives } \\
\text { Cellina } N \text {. }\end{array}$ \\
\hline Myristic acid C14:0 & n.d. & n.d. & n.d. & n.d. & n.d. & n.d. & n.d. & n.d. \\
\hline Palmitic acid C16:0 & 11.8 & 11.4 & 9.8 & 15.1 & 14.7 & 10.1 & 13.6 & 19.6 \\
\hline Palmitoleic acid C16:1 & 0.6 & 0.8 & 1.1 & 2.9 & 1.3 & 1.1 & 1.4 & 1.9 \\
\hline Heptadecanoic acid C17:0 & 0.1 & 0.1 & n.d. & 0.1 & n.d. & n.d. & 0.1 & n.d. \\
\hline Heptadecenoic acid C17:1 & 0.3 & 0.1 & 0.1 & 0.3 & 0.1 & 0.1 & 0.1 & n.d. \\
\hline Stearic acid C18:0 & 2.9 & 2.2 & 3.0 & 1.6 & 1.7 & 1.7 & 1.8 & 2.2 \\
\hline Oleic acid C18:1 & 76.4 & 79.6 & 76.8 & 63.4 & 70.2 & 80.7 & 76.5 & 70.8 \\
\hline Linoleic acid C18:2 $\omega 6$ & 6.3 & 4.7 & 8.0 & 13.6 & 10.7 & 5.2 & 5.5 & 4.7 \\
\hline Arachic acid C20:0 & 0.8 & 0,4 & 0.4 & 0.3 & 0.3 & 0.2 & 0.3 & 0.4 \\
\hline Linolenic acid C18:3 $\omega 3$ & 0.5 & 0.7 & 0.5 & 0.6 & 0.7 & 0.6 & 0.5 & 0.2 \\
\hline Eicosenoic acid C20:1 & 0.3 & 0.2 & 0.3 & 0.2 & 0.2 & 0.2 & 0.3 & 0.2 \\
\hline Behenic acid C22:0 & 0.1 & n.d. & 0.1 & 0.1 & 0.1 & 0.1 & 0.1 & 0.1 \\
\hline Lignoceric acid C24:0 & n.d. & 0.1 & n.d. & n.d. & n.d. & n.d. & 0.1 & 0.1 \\
\hline Trans fatty acids & 0.02 & $\operatorname{tr}$ & 0.02 & 0.01 & $\operatorname{tr}$ & $\operatorname{tr}$ & 0.01 & $\operatorname{tr}$ \\
\hline
\end{tabular}

Table 5. Fatty acid composition percentage of some Italian table olives. $n . d .=$ not detected; $\operatorname{tr}=\operatorname{traces}$.

Monounsaturated fatty acids (MUFA) were the major group (66.8-82.1\%), saturated fatty acids (SFA) represented less than $22.4 \%$ and polyunsaturated fatty acids (PUFA) range 4.9$14.2 \%$. The trans fatty acids had a very limited occurrence (less than $0.02 \%$ ). The intake of $\alpha-$ linolenic acid (C18:3 $\omega 3$ ), precursor for the synthesis of long chain $\omega 3$ fatty acids, is appreciable but the ratio $\omega 6: \omega 3$ is still too far towards $\omega 6$ and depends on the cultivar (6.723.5; Table 5). Several sources of information suggest that human beings evolved on a diet with a ratio of $\omega 6$ to $\omega 3$ essential fatty acids of approximately 1 whereas in Western diets the ratio is 15-16.7. Western diets are deficient in omega-3 fatty acids, and have excessive amounts of omega- 6 fatty acids compared with the diet on which human beings evolved and their genetic patterns were established (Simopoulos, 2008). The ratio of oleic to palmitic acid in dietary fats has a regulatory influence on certain thrombogenic and fibrinolytic markers during the postprandial state in healthy subjects (Pacheco et al., 2006). It has a recommended ratio of at least 5 . Also the polyunsaturated/saturated fatty acid (PUFA/SFA) ratio is used to assess the nutritional quality of the lipid fraction in foods. Consumption of saturated fatty acids has been associated with coronary heart disease (Serrano et al., 2005). Consequently, nutritional guidelines have recommended that the PUFA/SFA ratio should be above 0.4-0.5 (Wood et al., 2008). The mean values of the indexes (cis PUFA/SFA + TFA) and (cis MUFA + cis PUFA/SFA + TFA), which were most commonly used to express nutritional value of edible fats (Alonso et al. 2002; Anwar et al., 2006; Garrido-Fernandez, 2008), presented very high values due to the absence of trans fatty acids. These results are in 
accordance, but even higher, with those found for "alcaparra" olives (0.3 and 5.0, respectively; Sousa et al., 2011). Only for Cellina di Nardò olives these indexes are lower for "alcaparra" olives (Table 6).

\begin{tabular}{|l|c|c|c|c|c|c|c|c|}
\hline Fatty acid index & $\begin{array}{c}\text { Sevillan } \\
\text { green } \\
\text { olives } \\
\text { Intosso }\end{array}$ & $\begin{array}{c}\text { Sevillan } \\
\text { green } \\
\text { olives } \\
\text { Bella di } \\
\text { Cerignola }\end{array}$ & $\begin{array}{c}\text { Ferrandin } \\
\text { a black } \\
\text { olives } \\
\text { Majatica }\end{array}$ & $\begin{array}{c}\text { Natural } \\
\text { black } \\
\text { olives } \\
\text { Moresca }\end{array}$ & $\begin{array}{c}\text { Natural } \\
\text { black } \\
\text { olives } \\
\text { Peranzana }\end{array}$ & $\begin{array}{c}\text { Natural } \\
\text { black } \\
\text { olives } \\
\text { Itrana }\end{array}$ & $\begin{array}{c}\text { Natural } \\
\text { green } \\
\text { olives } \\
\text { Itrana }\end{array}$ & $\begin{array}{c}\text { Natural } \\
\text { black } \\
\text { olives } \\
\text { Cellina N. }\end{array}$ \\
\hline SFA & 15.7 & 14.2 & 13.3 & 17.2 & 16.8 & 12.1 & 16.0 & 22.4 \\
\hline MUFA & 77.6 & 80.7 & 78.3 & 66.8 & 71.8 & 82.1 & 78.3 & 72.9 \\
\hline PUFA & 6.8 & 5.4 & 8.5 & 14.2 & 11.4 & 5.8 & 6.0 & 4.9 \\
\hline MUFA/SFA & 4.9 & 5.7 & 5.9 & 3.9 & 4.3 & 6.8 & 4.9 & 3.3 \\
\hline PUFA/SFA & 0.4 & 0.4 & 0.6 & 0.8 & 0.7 & 0.5 & 0.4 & 0.2 \\
\hline $\begin{array}{l}\text { (cis MUFA cis } \\
\text { PUFA/(SFA+TFA) }\end{array}$ & 5.4 & 6.1 & 6.5 & 4.7 & 5.0 & 7.3 & 5.3 & 3.5 \\
\hline cis PUFA/(SFA+TFA) & 0.4 & 0.4 & 0.6 & 0.8 & 0.7 & 0.5 & 0.4 & 0.2 \\
\hline Oleic/palmitic & 6.5 & 7.0 & 7.8 & 4.2 & 4.8 & 8.0 & 5.6 & 3.6 \\
\hline $66 / \omega 3$ & 12.6 & 6.7 & 16.0 & 22.7 & 15.3 & 8.7 & 11.0 & 23.5 \\
\hline
\end{tabular}

Table 6. Fatty acid indexes.

As regard to sterol, fatty and triterpenic alcohol composition, there are some studies relating to the changes during processing (López- López et al., 2008, 2009). The main phytosterols and phytostanols found in Ferrandina table olives (Table 7) are $\beta$-sitosterol (59.1-89.6 \%) and $\Delta 5$-avenasterol (1.5-34.3\%), followed by campesterol (1.8-4.2\%), $\Delta 5,24$-stigmastadienol $(0.4-$ $1.2 \%)$ and chlerosterol (1.0-1.5\%). The low content of $\beta$-sitosterol and high content of $\Delta 5-$ avenasterol in Majatica olives is typical for this cultivar (Rotundo \& Marone, 2002), but $\beta$ sitosterol (including $\Delta 5,23$-stigmastadienol, clerosterol, $\beta$-sitosterol, sitostanol, $\Delta 5$ avenasterol and $\Delta 5,24$-stigmastadienol) is higher than $93 \%$, the limit fixed for extra virgin olive oil (EVOO) by the Commission Regulation (EEC) 2568/91 and its subsequent modifications. Epidemiologic and experimental studies suggest that dietary phytosterols, and in particular $\beta$-sitosterol, may offer protection from the most common cancers in Western societies, such as colon, breast and prostate cancer and contribute to lower the cardiovascular disease risk. (Awad \& Fink, 2000; Woyengo et al., 2009).

Finally, table olives could be utilized as a vehicle for incorporating probiotic bacteria and transporting bacterial cells into the human gastrointestinal tract. Food industries are now focusing on new foods which are part of a normal diet and can contribute to a regular assumption of probiotics (functional foods). The incorporation of health-promoting bacteria into table olives would add functional features to their current nutritional properties.

The consumption of table olives, in combination with the consumption of olive oil, which are basic components of the Mediterranean diet, provide a large amount of natural compounds of nutraceutical value (polyphenols, phytosterols and fatty acids) with antioxidant, anti-inflammatory or hormone-like properties. 


\begin{tabular}{|c|c|c|c|c|c|c|c|c|}
\hline Sterol & $\begin{array}{l}\text { Sevillan } \\
\text { green } \\
\text { olives } \\
\text { Bella di } \\
\text { Cerignola }\end{array}$ & $\begin{array}{c}\text { Castelvetrano } \\
\text { green } \\
\text { olives } \\
\text { Nocellara B. }\end{array}$ & $\begin{array}{c}\text { Ferrandina } \\
\text { black } \\
\text { olives } \\
\text { Majatica }\end{array}$ & $\begin{array}{c}\text { Natural } \\
\text { black } \\
\text { olives } \\
\text { Moresca }\end{array}$ & $\begin{array}{c}\text { Natural } \\
\text { black } \\
\text { olives } \\
\text { Peranzana }\end{array}$ & $\begin{array}{c}\text { Natural } \\
\text { black } \\
\text { olives } \\
\text { Itrana }\end{array}$ & $\begin{array}{l}\text { Natural } \\
\text { green } \\
\text { olives } \\
\text { Itrana }\end{array}$ & $\begin{array}{c}\text { Natural } \\
\text { black } \\
\text { olives } \\
\text { Cellina } N .\end{array}$ \\
\hline Cholesterol & 0.8 & 1.4 & 0.4 & 0.8 & 0.5 & 0.4 & 0.5 & 0.6 \\
\hline Brassicasterol & 0.1 & 0.3 & 0.1 & 0.1 & n.d. & n.d. & 0.1 & n.d. \\
\hline 24-methylen cholesterol & n.d. & 0.2 & 0.5 & n.d. & 0.2 & 0.1 & 0.1 & 0.2 \\
\hline Campesterol & 3.1 & 4.2 & 1.8 & 2.1 & 2.0 & 2.6 & 2.4 & 3.1 \\
\hline Campestanol & n.d. & 0.1 & 0.1 & 0.2 & 0.4 & n.d. & n.d. & 0.2 \\
\hline Stigmasterol & 1.2 & 1.8 & 0.5 & 1.0 & 0.7 & 0.4 & 0.7 & 0.9 \\
\hline$\Delta 7$-campesterol & 0.7 & 0.2 & 0.1 & 0.6 & 0.3 & 0.8 & 0.6 & 0.3 \\
\hline$\Delta 5,23$-stigmastadienol & n.d. & n.d. & 0.1 & n.d. & n.d. & n.d. & n.d. & 0.1 \\
\hline Chlerosterol & 1.5 & 1.4 & 1.0 & 1.5 & 1.2 & 1.0 & 1,0 & 1.0 \\
\hline$\beta$-sytosterol & 89.6 & 84.5 & 59.1 & 80.2 & 77.4 & 87.8 & 88.7 & 85.4 \\
\hline Sitostanol & 1.3 & 0.6 & 0.4 & 2.5 & 0.6 & 0.6 & 0.7 & 2.3 \\
\hline$\Delta 5$-avenasterol & 1.5 & 4.7 & 34.3 & 8.5 & 15.9 & 5.6 & 4.3 & 5.3 \\
\hline$\Delta 5,24$-stigmastadienol & 0.1 & 0.6 & 1.2 & 1.0 & 0.5 & 0.4 & 0.6 & 0.7 \\
\hline$\Delta 7$-stigmastenol & 0.3 & n.d. & 0.3 & 0.7 & 0.2 & 0.2 & 0.3 & 0.1 \\
\hline$\Delta 7$-avenasterol & 0.3 & n.d. & 0.1 & 0.8 & 0.2 & 0.2 & 0.2 & 0.1 \\
\hline
\end{tabular}

Table 7. Sterolic composition (\%) of some Italian table olives. n.d. = not detected.

\subsection{The nutritional label}

A separate discussion is made about nutritional labelling which, while optional until 13 December 2016, could add value to our product. What information do we expect to find on a nutrition label of a jar of olives? Currently the provision of a nutrition label is regulated by the Regulation (EU) 1169/2011 of the European Parliament and of the Council on nutrition labelling for foodstuffs as regards recommended daily allowances, energy conversion factors and definitions. The information written on the label should be referred to $100 \mathrm{~g}$ of product: in the case of whole olives reference should be made to $100 \mathrm{~g}$ of drained product (therefore considering the stone even if not edible) or $100 \mathrm{~g}$ of edible portion (in this case only the pulp of olives). For pitted olives and olive paste this problem does not arise. The nutritional information may also be referred to as a portion or "serving size", based on the amount of food consumed by a person. For table olives, a serving size could be formed by about 10 medium-sized olives and expressed in grams (taking into account the weight of the stone). It is also useful to relate the content of each nutrient with a daily reference value for a diet of $2000 \mathrm{kcal}$ of an average weight adult performing limited physical activity. Percentages above $20 \%$ are considered significant, below $5 \%$ modest.

\section{The IOC Method for the sensory analysis of table olives}

Since 21 November 2008 the procedure for the classification of table olives based on parameters of quality has become official: COI/OT/MO/Doc. No 1. Method for the sensory 
analysis of table olives. On 25 November 2011 (Decision No DEC-18/99-V/2011) the International Olive Council adopted the revised version of the method (COI/OT/MO No $1 /$ Rev. 2). The method establishes the necessary criteria and procedures for the sensory analysis of the odour, taste and texture of table olives and sets out the systematics for their commercial classification. It is applicable solely to the fruit of the cultivated olive tree (Olea europaea L.) which has been suitably treated or processed and which has been prepared for trade or for final consumption as table olives in accordance with the trade standard applying to table olives referenced COI/OT/NC No 1 (2004).

\subsection{The panel}

The sensory evaluation of table olives is done by a group of 8-10 expert tasters selected on the basis of aptitude and led by a panel leader. This group constitutes the taste panel. The tasters are chosen by means of a selection process implemented in accordance with an international standard according to his/her sensitivity and discriminatory power with regard to the organoleptic characteristics of table olives, who becomes skilled after suitable training and whose performance is objectively evaluated on the basis of rules established beforehand by the leader of the panel to which the taster belongs. The panel leader is the person whose chief duties are to lead panel activities, including taster recruitment, selection, training, skill building and monitoring. He/she designs and leads the sensory tests and analyses and interprets the data and may be assisted by one or more panel technicians.

\subsection{Main facilities and equipment of test room}

Tasting booth, referred to standard COI/T.20/Doc. No 6/Rev. 1 Guide for the installation of a test room or to ISO 8589:2007 General guidance for the design of test rooms;

Glasses, according to standard COI/T.20/Doc. No 5 Glass for oil tasting, covered with watchglasses;

Plastic or metal cocktail sticks, two-pronged forks, spoons or tongs;

Profile sheet on hard or soft copy. The line for each attribute must measure exactly $10 \mathrm{~cm}$.

\subsection{Sample presentation and tasting session}

The sample of table olives for analysis shall be presented in standard tasting glasses (Figure 4). The glass shall contain as many olives as the bottom of the glass can hold when the olives are placed side by side in a single layer. When brined table olives are undergoing analysis, sufficient covering liquid shall be poured over the olives to cover them fully. When the olives are above the 91/100 size-grade, the volume of sample contained in the glass shall in no case be more than half the height of the glass (i.e. $30 \mathrm{~mm}$ ). In the case of table olives belonging to a size-grade below 91/100, the sample for testing in the glass shall comprise no less than three olives. When brined table olives are undergoing analysis, the quantity of covering liquid in the glass shall come up to at least three-quarters of the height of the olives. The glass shall be covered with the attendant watch-glass. 


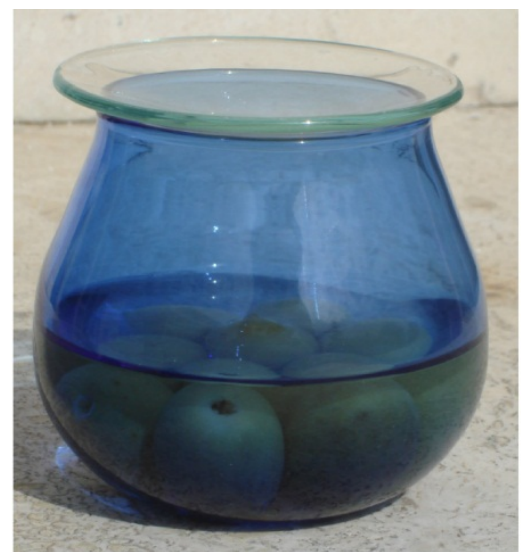

(a) olives above the $91 / 100$ size-grade

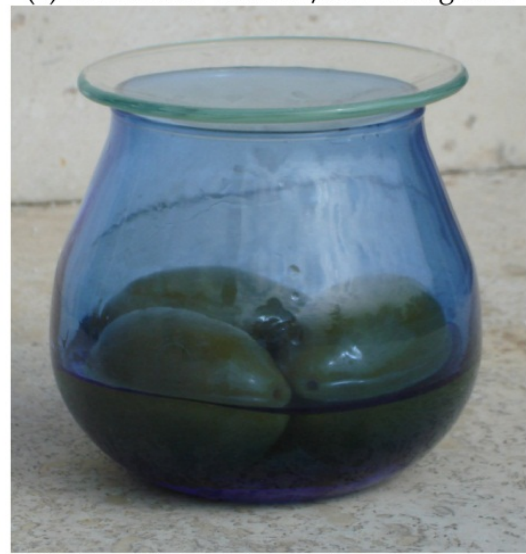

(b) olives below the 91/100 size-grade

Figure 4. Different distribution of olives and brine in the glass.

The samples of table olives intended for tasting shall be kept in the glasses at ambient temperature, between 20 and $25{ }^{\circ} \mathrm{C}$, under white light (daylight). To avoid tasting fatigue and the appearance of bias or contrast effects, each tasting session should entail the sensory analysis of not more than three samples. Between each session the tasters should rinse out their mouth fully and take a break of at least fifteen minutes. No more than three tasting sessions should be conducted in any given day. It should be kept in mind that the morning, before lunch, is the period when olfactory-gustatory sharpness is optimal (between 10 a.m. and 12 noon).

\subsection{Tasting session and use of the profile sheet by tasters}

The tasters shall pick up the glass, keeping it covered with the watch-glass, and shall bend it gently to help the sample aromas to be released and blended. After doing so, they shall 
remove the watch-glass and smell the sample, taking slow deep breaths to evaluate the direct olfactory sensations cited in the profile sheet. Smelling shall not last more than 20 seconds. If no conclusion has been reached during this time, the tasters shall take a short rest before trying again. The tasters shall then assess the other sensations cited in the profile sheet. To do so, they shall place one of the olives contained in the glass in their mouth; they shall chew the olive after removing the stone, making sure to spread the chewed olive throughout the whole of the mouth cavity. They shall concentrate on the order of appearance of the salty, bitter and acid stimuli, the retronasal olfactory sensations and the kinaesthetic sensations of hardness, crunchiness and fibrousness and shall assess the intensity of each of these sensations by making the corresponding mark on the intensity scale of the tasting sheet. Next they shall spit out the chewed olives, rinse out their mouth with water and recommence the assessment of the sensations produced by each of the olives contained in the glass. They shall enter the intensity with which they perceive each of the attributes in the scales of the profile sheet provided. Tasters may refrain from placing the olives in their mouth when they observe an extremely intense negative attribute. They shall record this exceptional circumstance in the profile sheet. They must, however, mark the intensity of the odorous attribute on the corresponding scale. They shall enter in the profile sheet the intensity of each of the sensations perceived when smelling and chewing the olives.

\subsection{Attributes to be perceived}

\subsubsection{Negative attributes}

Unpleasant sensations are caused by the production of substances responsible for offodours, which are not present in the fresh fruit or formed during well-performed processing treatments. The term "abnormal fermentation" includes all those olfactory sensations perceived directly or retronasally, reminiscent of the odour of decomposing organic matter, cheese, butter, rotten eggs, muddy sediment, sewer, rotten leather, caused by the development of contaminating microorganisms (butyric fermentation, putrid fermentation and zapateria). If the tasters perceive any negative attributes other than abnormal fermentations, they shall record them under the 'other defects' heading, using the following terms: musty, rancid, cooking effect, soapy, metallic, earthy and winey/vinegary. Musty sensation is an olfactory-gustatory sensation perceived directly or retronasally, characteristic of olives attacked by moulds. Rancid sensation is an olfactory sensation perceived directly or retronasally, characteristic of olives that have undergone a process of rancidity. Cooking effect is an olfactory sensation perceived directly or retronasally, characteristic of olives that have undergone excessive heating in terms of temperature and/or duration during pasteurisation or sterilisation. This taste may be typical of some cooked preparations as oven-dried black olives. Winey-vinegary is an olfactory-gustatory sensation reminiscent of wine or vinegar. Winey-vinegary taste should not be confused with the acid sensation. The defect wineyvinegary is due to alcoholic fermentation by yeasts, while the feeling of acid defines the taste associated with acids naturally present or produced during the lactic fermentation by homo 
and hetero fermentative lactic acid bacteria. Both sensations may be more or less marked by inappropriate use of acids used as acidity correctors (e.g., acetic or citric acid), but may also be typical of some preparations involving the use of vinegar (e.g., Kalamata olives). Soapy is an olfactory-gustatory sensation reminiscent of soap. This taste is found primarily in olives treated with lye (Spanish and Castelvetrano systems) and not sufficiently rinsed with water or consumed shortly after debittering. Metallic is an olfactory-gustatory sensation reminiscent of metals. It is found primarily in olives darkened by oxidation with the addition of iron salts such as gluconate or ferrous lactate, used as stabilizers of the color (eg. Californian black olives), but can also be perceived of olives preserved in metal packs. Earthy is an olfactory-gustatory sensation reminiscent of soil or dust. It is found in olives that have been in contact with soil and dust for a long time, usually harvested after they fall from the tree.

\subsubsection{Descriptive gustatory attributes}

The gustatory sensations involve distinct areas of tongue: the region affected by the perception of salty taste is the lateral-anterior, the region affected by the perception of acid taste is the posterior and the region affected by the perception of bitter taste is the basis of tongue. The salty sensation is associated to the basic taste produced by aqueous solutions of substances such as sodium chloride and depends on the concentration of fermentation or conditioning brines. The bitter sensation is associated to the basic taste produced by dilute aqueous solutions of substances such as quinine or caffeine and depends on the presence of bitter substances, mainly polyphenols. It may therefore be more intense in preparations in which the debittering, incomplete, is due to the action of microrganisms (natural olives). The acid sensation is associated to the basic taste produced by dilute aqueous solutions of most acid substances, such as tartaric or citric acids. It defines the taste associated with acids naturally present in the olive flesh (e.g., tartaric acid, malic acid or citric acid) or produced during the lactic fermentation by homo and heterofermentative lactic acid bacteria (e.g., lactic acid or acetic acid), but may also depend on the inappropriate use of acids as correctives of acidity (e.g., citric acid). High level of acid sensation is also found in the olives whose preparation involves the addition of vinegar (e.g., Kalamata olives).

\subsubsection{Kinaesthetic sensations (texture)}

With the term "kinaesthetic sensations" (from the greek $\kappa \iota v \eta \sigma \eta=$ movement and $\alpha \iota \sigma \theta \eta \sigma \eta=$ sense) are indicated the sensations deriving from the contact of the fruit with the mouth. We could translate it as "musculoskeletal overall perception, in the oral cavity, of the mechanical characteristics of the fruit". Texture is defined as the set of rheological (related to the flow and deformation of matter) and structural (geometrical and surface) properties of a product perceptible to the mechanical receptors, tactile receptors and in some cases the visual and auditory receptors. The following attributes are assessed in table olives: hardness, 
crunchiness and fibrousness. Hardness is defined as the mechanical properties of consistency related to the force required to obtain the deformation or penetration of a product. It is perceived through the compression of the product between the teeth (solid products) or between the tongue and palate (semi-solid products); as regards the solid products such as table olives, the force required to compress the product is evaluated first between the incisors (Hardness 1), then between the molars (Hardness 2) and finally during mastication (Hardness 3) (Kim et al., 2012). Crunchiness is the property related to the noise produced by friction or fracture between two surfaces. In our case, it is related to the force required to fracture a product with the teeth and is determined by compressing the fruit between the molars. Fibrousness is a geometric textural attribute relating to the perception of the shape and the orientation of particles in a product. Fibrousness refers to the elongated conformation of the particles, oriented in the same direction. It is evaluated by perceiving the fibres between the tongue and palate when chewing the olive. Hardness, crunchiness and fibrousness may also be assessed by instrumental puncture, compression, stretching and acoustic tests using Texture Analyzer. The texture of edible fruits and vegetables is strongly influenced by the chemical, physical and structural properties of the plant cell walls which surround every cell and, through adhesion to the adjacent ones, provide mechanical strength and protection (Brett \& Waldron, 1996). Such properties will be affected by the stage of ripening (Mafra et al., 2001) and processing technologies (Lanza \& Marsilio, 2001; Tassou et al., 2007). Tissues in which cell-to-cell adhesion is very strong may only be disrupted by breakage of the cell walls: such tissues are usually crunchy in texture. Tissues in which cell-to-cell adhesion is very weak may be disrupted through cleavage along the plane of the middle lamella: such tissues are usually soft in texture. The examination of the fracture surface can indicate whether tissue failure occurs as a result of cell rupture or cellto-cell debonding. A simple olive fracturing method is described in Lanza et al. (2010a). In a recent research (Lanza \& Di Serio, 2011), information provided by sensory and other instrumental measurements of tissue hardness were compared with that provided by scanning electron microscopy. The different levels of hardness applied to olives by sensory analysis are as follows: soft (low level), firm (moderate level) and hard (high level). Fractured epicarp and mesocarp olive fruits in longitudinal view, corresponding to the three levels of hardness, were examined by SEM (Figure 5). In hard olives, the thin-walled parenchyma cells were uniform and tightly packed. Tissue fracture involved cell walls breaking, both in epicarp and mesocarp and cell separation at the middle lamella level was not observed. The fracture surface of firm olives consisted of two regions: (a) one with 400$500 \mu \mathrm{m}$ containing broken cell walls and some separated cells and (b) a second one containing intact cell walls. The region with broken cell walls extended from the olive epidermis as far as the eighth-ninth layer of mesocarp. In soft olives, the region of broken cell walls was smaller $(100-200 \mu \mathrm{m})$ and involved only the epicarp and the first layers of the mesocarp (hypodermis and, sometimes, the following first layer). The other cells showed rounded outlines and were divided along the middle lamella, showing cell separation. Summarizing, in hard fruits, tissue fracture involves cell walls breaking and the thin-walled 
parenchyma cells olives are uniform and tightly packed (cell rupture). In soft olives the cells show rounded outlines and are divided along the middle lamella (cell separation). This is due to an increase in cell separation which consists mainly in the dissolution of middle lamella pectic polysaccharides.

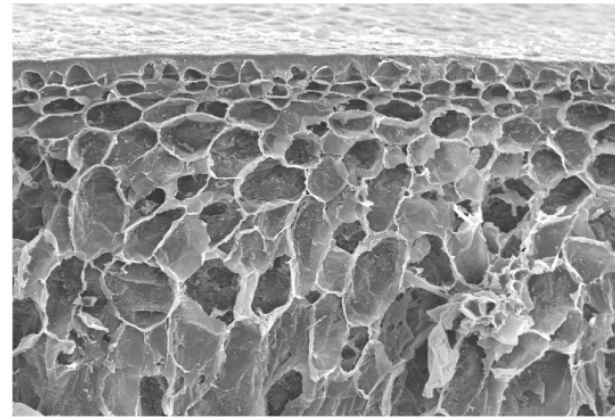

- All broken cells (by SEM)

- H median value $>6$ (by Sensory Analysis)

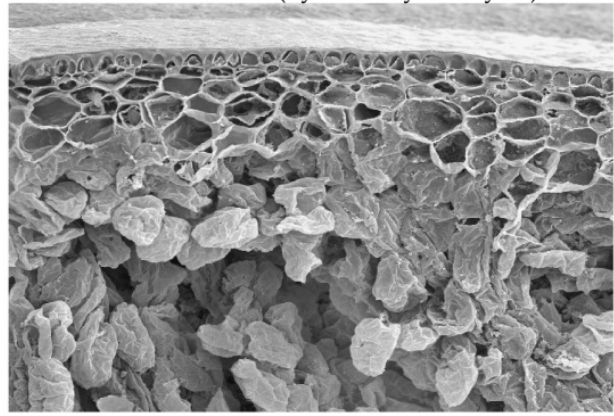

- 100-200 $\mu \mathrm{m}$ of broken cells (by SEM)

- $\mathrm{H}$ median value $\leq 2$ (by Sensory Analysis)

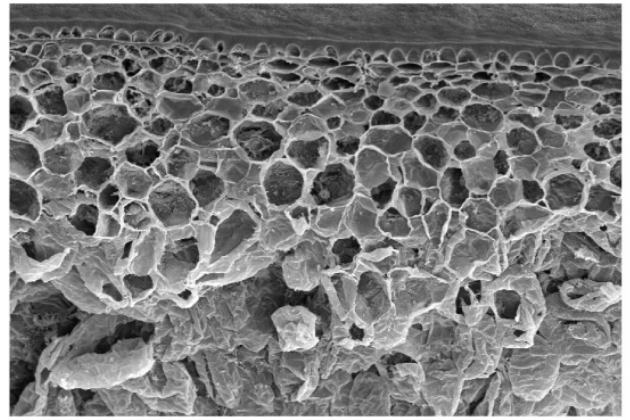

- $400-500 \mu \mathrm{m}$ of broken cells (by SEM)

- $<2 \mathrm{H}$ median value $\leq 6$ (by Sensory Analysis)

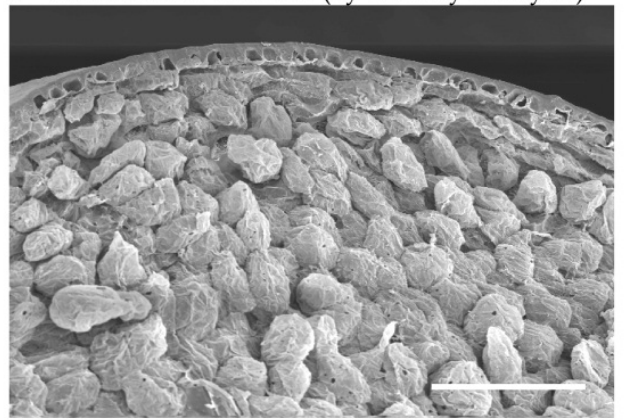

- All separated cells (by SEM)

- Not detected (by Sensory Analysis)

Figure 5. The different levels of hardness $(\mathrm{H}) . \mathrm{Bar}=300 \mu \mathrm{m}$.

\subsection{Elaboration of sensory data}

The panel leaders shall collect the profile sheets completed by each of the tasters and shall review the intensities recorded for each of the descriptors. If they find any anomaly, they shall invite the taster concerned to revise the profile sheet and, if necessary, to repeat the test. The panel leaders shall determine the intensities of the attributes listed in the profile sheet by using a ruler to measure the segment running from the origin of the scale to the mark made by the taster. When this mark lies between two notches on the ruler, they shall assign the value lying closest to one of the notches. The segment shall be expressed to one decimal place. The scale shall measure $10 \mathrm{~cm}$ long and the intensity shall range from 1 to 11 . The panel leaders shall apply the method for calculating the median and the confidence intervals according to the method contained in Annex 1 (COI/OT/MO/n ${ }^{\circ} 1 / \operatorname{Rev} .2$ Annex 1 Method for calculating the median and the confidence intervals) and shall only take into account 
those attributes with a robust coefficient of variation of $20 \%$ or less. The computer program for carrying out the calculations is presented in Annex 3 (COI/OT/MO/n ${ }^{\circ} 1 / \operatorname{Rev} .2$ Annex 3 Sensory analysis of table olives computer program). When a defect is entered under the 'Other defects' heading by at least 50 percent of the panel tasters, the panel leaders shall carry out the statistical calculation of this defect and shall arrive at the corresponding classification if the coefficient of variation is $20 \%$ or less.

\subsection{Classification according to the defect predominantly perceived (DPP)}

For classification purposes, the panel leader shall solely take into account the median of the defect predominantly perceived (DPP) i.e. perceived with the greatest intensity, that satisfies the requirements specified in the preceding paragraph. According to the intensity of DPP, the samples shall be classified in four categories:

Extra or Fancy: DPP $\leq 3$

First, 1st, Choice or Select: $3<\mathrm{DPP} \leq 4.5$

Second, 2nd or Standard: $4.5<\mathrm{DPP} \leq 7.0$

Olives that may not be sold as table olives: DPP $>7.0$

The organoleptic analysis of table olives deriving by the same variety (Itrana) but processed at a different stage of ripening ("Oliva bianca di Itri" and "Oliva nera di Gaeta") shows a different sensory profile with regard to kinaesthetic properties (hardness, fibrousness and crunchiness) and bitter sensation (Figure $6 a$ and b) (Lanza et al., 2010b). The organoleptic analysis of table olives deriving by the same variety (Itrana) and processing ("Oliva Bianca di Itri") show a different sensory profile between undefected and defected samples. Defected samples show a decrease in kinaesthetic properties (hardness, fibrousness and crunchiness) and an increase in acid sensation (Figure $7 a$ and $b$ ). The median value of DPP is less or equal to 3 and the olives remain of "Extra or Fancy" category.
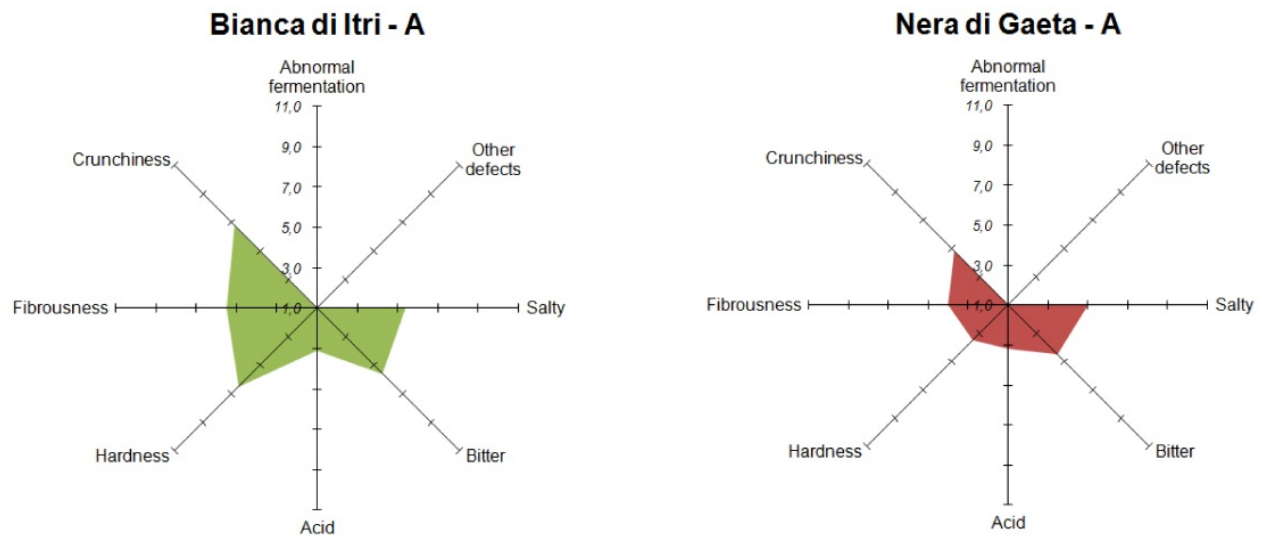

Figure 6. Sensory profiles of "Oliva bianca di Itri" and "Oliva nera di Gaeta". 

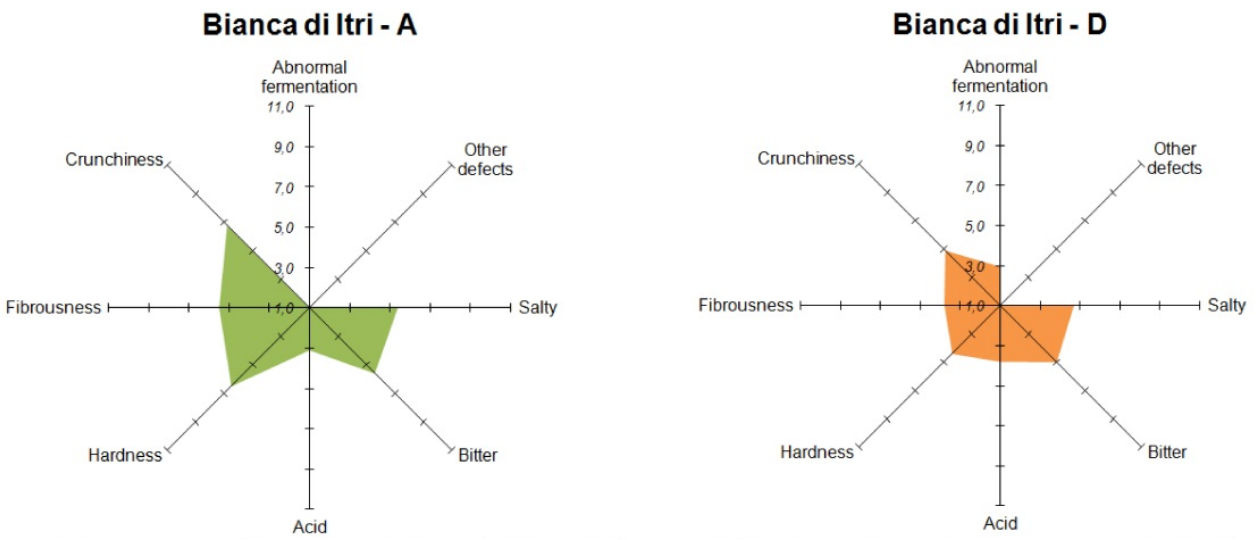

Figure 7. Sensory profiles of undefected (a) and defected (b) olives from "Oliva bianca di Itri".

\section{Acknowledgement}

Financial support for this study was provided by Italian Ministry of Agriculture, Food and Forestry through the project GERMOLI "Salvaguardia e valorizzazione del GERMoplasma OLIvicolo delle collezioni del CRA-OLI".

\section{Author details}

Barbara Lanza

Agricultural Research Council - Olive Growing and Oil Industry Research Centre, Città Sant'Angelo (PE), Italy

\section{References}

Alonso, L., Fraga, M.J., Juarez, M. \& Carmona, P. (2002). Fatty acid composition of Spanish shortening with special emphasis on trans unsaturated content as determination by Fourier transform infrared spectroscopy and gas chromatography, Journal of American Oil Chemistry Society 79: 1-6.

Alves, M., Gonçalves, T. \& Quintas, C. (2012). Microbial quality and yeast population dynamics in cracked green table olives fermentations, Food Control 23: 363-368.

Anwar, F., Bhanger, M.I., Iqbal, S. \& Sultana, B. (2006). Fatty acid composition of different margarines and butters from Pakistan with special emphasis on trans unsaturated contents, Journal of Food Quality, 29: 87-96.

Arroyo López, F.N., Querol, A., Bautista Gallego, J. \& Garrido Fernández, A. (2008). Role of yeasts in table olive production, International Journal of Food Microbiology 128: 189-96.

Awad, A.B. \& Fink, C.S. (2000). Phytosterols as anticancer dietary components: evidence and mechanism of action, Journal of Nutrition 130: 2127-2130. 
Baiano, A., Gambacorta, G., Terracone, C., Previtali, M.A. \& La Notte, E. (2009). Characterization of drupes, phenolic content and antioxidant capacity of Italian olive fruits, Journal of Food Lipids 16: 209-226.

Balatsouras, G. (1990). Edible olive cultivars, chemical composition of fruit, harvesting, transportation, processing, sorting and packaging, styles of black olives, deteriorations, quality standards, chemical analyses, nutritional and biological value of the product. Proceedings of International Seminar "Olio d'oliva e olive da tavola: tecnologia e qualità", Citta di S. Angelo (Pe), Italy.

Bautista Gallego, J., Arroyo López, F.N., Romero Gil, V., Rodríguez Gómez, F., García García, P. \& Garrido Fernández, A. (2011). Chloride salt mixtures affect Gordal cv. green Spanish-style table olive fermentation, Food Microbiology 28: 1316-25.

Beauchamp, G.K., Keast, R.S.J., Morel, D., Lin, J., Pika, J., Han, Q., Lee, C-H., Smith, A.B. \& Breslin, P.A.S. (2005). Ibuprofen-like activity in extra-virgin olive oil, Nature 437: 45-46.

Ben Othman, N., Roblain, D., Thonart, P. \& Hamdi, M. (2008). Tunisian table olive phenolic compounds and their antioxidant capacity, Journal of Food Science 73: C235-40.

Bevilacqua, A., Altieri, C., Corbo, M.R., Sinigaglia, M. \& Ouoba, L.I.I. (2010). Characterization of lactic acid bacteria isolated from Italian Bella di Cerignola table olives: selection of potential multifunctional starter cultures, Journal of Food Science, 75: M536-M544.

Bianchi, G. (2003). Lipids and phenols in table olives, European Journal of Lipid Science and Technology 105: 229-242.

Blekas, G., Vassilakis, C., Harizanis, C., Tsimidou, M. \& Boskou D.G. (2002). Biophenols in table olives, Journal of Agriculture and Food Chemistry 50: 3688-3692.

Borzillo, A., Iannotta, N. \& Uccella, N. (2000). Oinotria table olives: quality evaluation during ripening and processing by biomolecular components, European Food Research and Technology 212: 113-121.

Boskou, G., Salta, F.N., Chrysostomou, S., Mylona, A., Chiou, A. \& Andrikopoulos, N.K. (2006). Antioxidant capacity and phenolic profile of table olives from the Greek market, Food Chemistry 94: 558-564.

Brett, C.T. \& Waldron, K.W. (1996). Physiology and biochemistry of plant cell walls, Chapman \& Hall, London, UK.

Cannata, U. (1939). Potenzialità nutritiva dell'oliva da mensa, L'Italia Vinicola e Agraria 12:14.

Cappello, A. \& Poiana M. (2005). Le olive da tavola in Sicilia. Regione Siciliana Assessorato Agricoltura e Foreste - IX Servizio Regionale Servizi allo Sviluppo, Castelvetrano, Italy.

Cardoso, A.M., Mafra, I., Reis, A., Barros, A.S., Nunes, C., Georget, D.M.R., Smith, A., Saraiva, J., Waldron, K.W. \& Coimbra, M.A. (2009). Traditional and industrial oven-dry processing of olive fruits: influence on textural properties, cell wall polysaccharide composition, and enzymatic activity, European Food Research and Technology 229: 415-425.

Ciafardini, G., Marsilio, V., Lanza, B. \& Pozzi, N. (1994). Hydrolysis of oleuropein by Lactobacillus plantarum strains associated with olive fermentation, Applied and Environmental Microbiology 60: 4142-4147. 
Cucurachi, A., Vitagliano, M. \& Gervasi, P. (1971). Caratteristiche e utilizzazione delle olive "Majatica di Ferrandina", Annali dell'Istituto Sperimentale per la Elaiotecnica 1: 89-107.

De Castro, A., Montano, A., Casado F.J., Sanchez A.H. \& Rejano L. (2002). Utilization of Enterococcus casseliflavus and Lactobacillus pentosus as starter cultures for Spanish-style green olive fermentation, Food Microbiology 19: 637-644.

Di Gioia, D. (1959). Le olive infornate di Ferrandina, Olivicoltura 8: 6-12.

Garcia Garcia, P., Duran Quintana, M.C. \& Garrido Fernández, A. (1985). Fermentacion aerobica de aceitunas maduras en salmuera, Grasas y Aceites 36: 14-20.

Garrido Fernández, A. (2008). Revalorizacion nutricional de la aceituna de mesa. Proceedings of II International Table Olive Conference, Dos Hermanas, Sevilla, Spain.

Garrido Fernández, A., Fernandez Diez, M.J. \& Adams, M.R. (1997). Table Olives. Production and processing, Chapman \& Hall, London, UK.

Imura, K. \& Okada, A. (1998). Amino acid metabolism in pediatric patients, Nutrition 14: 143-148.

Issaoui, M., Dabbou, S., Mechri, B., Nakbi, A., Chehab, H. \& Hammami, M. (2011). Fatty acid profile, sugar composition, and antioxidant compounds of table olives as affected by different treatments, European Food Research and Technology 232: 867-876.

Jimenez, A., Rodriguez, R., Fernandez-Caro, I., Guillen, R., Fernandez-Bolanos, J. \& Heredia, A. (2000). Dietary fibre content of table olives processed under different European styles: study of physico-chemical characteristics, Journal of the Science of Food and Agriculture 80: 1903-1908.

Kim, E.H-J., Corrigan, V.K., Wilson, A.J., Waters, J.R., Hedderley, D.I. \& Morgenstern, M.P. (2012). Fundamental fracture properties associated with sensory hardness of brittle solid foods, Journal of Texture Studies 43: 49-62.

Lanza, B. \& Di Serio, M.G. (2011). Table olive hardness: relationship between ultrastructural and sensory analysis. Proceedings of 10th Multinational Congress on Microscopy, Urbino, Italy.

Lanza, B. \& Marsilio V. (2001). Microstructural changes in olive fruit as related to technoprocessing, Proceedings of 5th Multinational Congress on Electron Microscopy, Lecce, Italy.

Lanza, B. \& Poiana, M. (2011). Olive da tavola: tecnologia, Accademia Nazionale dell'Olivo e dell'Olio, Spoleto, Italy.

Lanza, B. (2010). L'Itrana non è solo nera. Le sei tipologie tradizionali, Olivo e Olio 9: 44-48.

Lanza, B. (2011). Enhancement of Italian traditional preparations of table olives and their nutraceutical properties. Proceedings of Olivebioteq 2011, Chania, Crete, Greece.

Lanza, B., Di Serio, M.G., Iannucci, E., Russi, F. \& Marfisi, P. (2010a). Nutritional, textural and sensorial characterisation of Italian table olives (Olea europaea L. cV. 'Intosso d'Abruzzo'), International Journal of Food Science and Technology 45: 67-74.

Lanza, B., Di Serio, M.G., Russi, F., D’Achille, G. \& Leonardi, G. (2010b). Organoleptic profile of Itrana table olives by IOC Method for the sensory analysis, Proceedings of III International Table Olive Conference, Sanlucar La Mayor, Seville, Spain.

Lanza, B., Di Serio, M.G., Russi, F., Iannucci, E., Giansante, L. \& Di Giacinto, L. (2012). Evaluation of nutritional value of oven-dried table olives (cv. Maiatica) processed by Ferrandina style, Journal of Food Composition and Analysis, in press. 
Lazovic, B., Miranovic, K., Gasic, O. \& Popovic, M. (1999). Olive protein content and amino acid composition, Acta Horticulturae 474: 465-468.

Leal-Sanchez, M.V., Ruiz-Barba, J.L., Sanchez, A.H., Rejano, L., Jimenez-Diaz, R. \& Garrido, A., (2003). Fermentation profile and optimization of green olive fermentation using Lactobacillus plantarum LPCO10 as a starter culture, Food Microbiology 20: 421-430.

López, A., Garrido, A. \& Montaño, A. (2007). Proteins and aminoacids in table olives: relationship to processing and commercial presentation, Italian Journal of Food Science 19: 217-228.

López, A., Montaño, A., Garcia, P. \& Garrido, A. (2006). Fatty acid profile of table olives and its multivarate characterization using unsupervised (PCA) and supervised (DA) chemometrics, Journal of Agriculture and Food Chemistry 54: 6747-6753.

López-López, A., Jiménez-Araujo, A., García-García, P. \& Garrido-Fernández, A. (2007). Multivariate analysis for the evaluation of fiber, sugars, and organic acids in commercial presentations of table olives, Journal of Agriculture and Food Chemistry 55: 10803-10811.

López-López, A., Montaño, A. \& Garrido-Fernández, A. (2010a). Nutrient profiles of commercial table olives: fatty acids, sterols, and fatty alcohols, in Preedy and Watson (eds.), Olives and olive oil in health and disease prevention. Elsevier, San Diego, CA. pp. 715723.

López-López, A., Montaño, A. \& Garrido-Fernández, A. (2010b). Nutrient profiles of commercial table olives: proteins and vitamins, in Preedy and Watson (eds.), Olives and olive oil in health and disease prevention. Elsevier, San Diego, CA. pp. 705-714.

López-López, A., Montaño, A., Ruíz-Méndez, M.V. \& Garrido-Fernández, A. (2008). Sterols, fatty alcohols, and triterpenic alcohols in commercial table olives, Journal of the American Oil Chemistry Society 85: 253-262.

López-López, A., Rodriguez-Gomez, F., Ruíz-Méndez, M.V., Cortes-Delgado, A. \& GarridoFernández, A. (2009). Sterols, fatty alcohol and triterpenic alcohol changes during ripe table olive processing, Food Chemistry 117: 127-134.

Mafra I., Lanza B., Reis A., Marsilio V., Campestre C., De Angelis M. \& Coimbra M.A. (2001). Effect of ripening on texture, microstructure and cell wall polysaccharide composition of olive fruit (Olea europaea), Physiologia Plantarum 111: 439-447.

Marsilio, V. \& Lanza, B. (1995). Effects of lye-treatment on the nutritional and microstructural characteristics of table olives (Olea europaea L.), Revista Espanola de Ciencia y Tecnologia de Alimentos 35: 178-190.

Marsilio, V. \& Lanza, B. (1998). Characterization of an oleuropein degrading strain of Lactobacillus plantarum. Combined effect of compounds present in olive fermenting brines (phenols, glucose and $\mathrm{NaCl}$ ) on bacterial activity, Journal of the Science of Food and Agriculture 76: 520-524.

Marsilio, V., Campestre, C., Lanza, B. \& De Angelis, M. (2001). Sugar and polyol compositions of some European olive fruit varieties (Olea europaea L.) suitable for table olive purposes, Food Chemistry 72: 485-490.

Marsilio, V., Campestre, C., Lanza, B., De Angelis, M. \& Russi, F. (2002). Sensory analysis of green table olives fermented in different saline solutions, Acta Horticulturae 586: 617-620. 
Marsilio, V., Lanza, B. \& Pozzi, N. (1996). Progress in table olives debittering: degradation in vitro of oleuropein and its derivatives by L. plantarum, Journal of American Oil Chemistry Society 73: 593-597.

Marsilio, V., Lanza, B., Campestre, C. \& De Angelis, M. (2000). Oven-dried table olives: textural properties as related to pectic composition, Journal of the Science of Food and Agriculture 80: 1271-1276.

Marsilio, V., Seghetti, L., Iannucci, E., Russi, F., Lanza, B. \& Felicioni, M. (2005). Use of a lactic acid bacteria starter culture during green olive (Olea europaea L., cv. Ascolana tenera) processing, Journal of the Science of Food and Agriculture 85: 1084-1090.

Montaño, A., Casado, F.J., de Castro, A., Sánchez, A.H. \& Rejano L. (2005). Influence of processing, storage time, and pasteurization upon tocopherol and amino acid contents of treated green table olives, European Food Research and Technology 220: 255-260.

Montaño, A., Sánchez, A.H., López-López, A., de Castro, A. \& Rejano, L. (2010). Chemical composition of fermented green olives: acidity, salt, moisture, fat, protein, ash, fiber, sugar and polyphenol, in Preedy and Watson (eds.), Olives and olive oil in health and disease prevention, Elsevier, San Diego, CA, pp. 291-297.

Pacheco, Y. M., Bermudez, B., Lopez, S., Abia, R., Villar, J. \& Muriana, F. J. G. (2006). Ratio of oleic to palmitic acid is a dietary determinant of thrombogenic and fibrinolytic factors during the postprandial state in men, American Journal of Clinical Nutrition 84: 342-349.

Panagou, E.Z. (2006). Greek dry-salted olives: monitoring the dry-salting process and subsequent physico-chemical and microbiological profile during storage under different packing conditions at 4 and $20^{\circ} \mathrm{C}$, LWT-Food Science and Technology 39: 322-329.

Panagou, E.Z., Hondrodimou, O., Mallouchos, A. \& Nychas, G.J. (2011). A study on the implications of $\mathrm{NaCl}$ reduction in the fermentation profile of Conservolea natural black olives, Food Microbiology 28: 1301-7.

Panagou, E.Z., Schillinger, U., Franz, C.M.A.P. \& Nychas G-J. E. (2008). Microbiological and biochemical profile of $\mathrm{cv}$. Conservolea naturally black olives during controlled fermentation with selected strains of lactic acid bacteria, Food Microbiology 25: 348-358.

Panagou, E.Z., Tassou, C.C. \& Katsaboxakis C.Z. (2003). Induced lactic acid fermentation of untreated green olives of the Conservolea cultivar by Lactobacillus pentosus, Journal of the Science of Food and Agriculture 83: 667-674.

Piga, A., Mincione, B., Runcio, A., Pinna, I., Agabbio, M. \& Poiana, M. (2005). Response to hot air drying of some olive cultivars of the south of Italy, Acta Alimentaria 34: 427-440.

Romero, C., Brenes, M., Yousfi, K., Garcia, P., Garcia, A. \& Garrido, A. (2004). Effect of cultivar and processing method on the contents of polyphenols in table olives, Journal of Agriculture and Food Chemistry 52: 479-484.

Rotundo, A. \& Marone, E. (2002). Il germoplasma olivicolo lucano, Tipolitografia Olita, Potenza, Italy.

Ruiz-Barba, J.L., Cathcart, D.P., Warner, P.J. \& Jimenez-Diaz, R. (1994). Use of Lactobacillus plantarum LPCO10, a bacteriocin producer, as a starter culture in Spanish-Style green olive fermentations, Applied and Environmental Microbiology 6: 2059-2064.

Sakouhi, F., Harrabi, S., Absalon, C., Sbei, K., Boukhchina, S. \& Kallel, H. (2008). $\alpha-$ tocopherol and fatty acids contents of some Tunisian table olives (Olea europaea L.): 
changes in their composition during ripening and processing, Food Chemistry 108: 833839.

Sánchez, A.H., Rejano, L., Montaño, A., De Castro, A. (2001). Utilization at high pH of starter cultures of lactobacilli for Spanish-style green olive fermentation, International Journal of Food Microbiology 67: 115-122.

Savastano, G. (1937). Sull'essiccamento delle olive nere di Ferrandina, L'olivicoltore 9: 11-17.

Schwartz, G.J., Fu, J., Astarita, G., Li, X., Gaetani, S., Campolongo, P., Cuomo, V. \& Piomelli, D. (2008). The lipid messenger OEA links dietary fat intake to satiety, Cell Metabolism 8: 281-288.

Serrano, A., Cofrades, S., Ruiz-Capillas, C., Olmedilla-Alonso, B., Herrero-Barbudo, C. \& Jiménez-Colmenero, F. (2005). Nutritional profile of restructured beef steak with added walnuts, Meat Science 70: 647-654.

Servili, M., Settanni, L., Veneziani, G., Esposto, S., Massitti, O., Taticchi, A., Urbani, S., Montedoro, G.F. \& Corsetti, A. (2006). The use of Lactobacillus pentosus $1 \mathrm{MO}$ to shorthen the debittering process time of black table olives (cv. Itrana and Leccino): a pilot-scale application, Journal of Agriculture and Food Chemistry 54: 3869-3875.

Simopoulos, A.P. (2008). The importance of the omega-6/omega-3 fatty acid ratio in cardiovascular disease and other chronic diseases, Experimental Biology and Medicine 233: 674-688.

Sousa, A Casal, S., Bento, A., Malheiro, R., Oliveira, M.B.P.P. \& Pereira, J.A. (2011). Chemical charactization of "Alcaparra" stoned table olives from Northeast Portugal, Molecules 16: 9025-9040.

Tassou, C., Katsaboxakis, C.Z., Georget, D., Parker, M.L, Waldron, K.W, Smith, A.C. \& Panagou, E.Z. (2007). Effect of calcium chloride on mechanical properties and microbiological characteristics of cv.Conservolea naturally black olives fermented at different sodium chloride levels, Journal of the Science of Food and Agriculture 87: 11231131.

Tavanti, G. (1819). Trattato teorico pratico completo sull'ulivo, Stamperia Piatti, Firenze, Italy.

Ünal, K. \& Nergiz, C. (2003). The effect of table olive preparing methods and storage on the composition and nutritive value of olives, Grasas y Aceites 54: 71-76.

Wood, J. D., Enser, M., Fisher, A. V., Nute, G. R., Sheard, P. R, Richardson, R. I., Huges, S. I. \& Whittington, F. M. (2008). Fat deposition, fatty acid composition and meat quality: A review, Meat Science 78: 343- 358.

Woyengo, T.A., Ramprasath, V.R. \& Jones, P.J. (2009). Anticancer effects of phytosterols, European Journal of Clinical Nutrition 63: 813-20.

Young, V.R. (1994). Adult amino acid requirements: the case for a major revision in current recommendations, Journal of Nutrition 124: 1517S-1523S. 